\title{
Digital Manufacturing of Gradient Meshed SOFC Sealing Composites with Self-Healing Capabilities
}

\author{
$\underline{\text { Final Scientific/Technical Report }}$
}

Period Covered by the Report: February 22, 2006-February 21, 2007

May 15, 2007

Award Number: DE-FG26-06NT42741

Virginia Polytechnic Institute and State University

213 Holden Hall, M/C 0237

Blacksburg, VA 24061

Phone: (540) 231-3225, Fax: (540)231-8919, E-mail: klu@vt.edu 


\section{Disclaimer}

This report was prepared as an account of work sponsored by an agency of the United States Government. Neither the United States Government nor any agency thereof, nor any of their employees, makes any warranty, express or implied, or assumes any legal liability or responsibility for the accuracy, completeness, or usefulness of any information, apparatus, product, or process disclosed, or presents that its use would not infringe privately owned rights. Reference herein to any specific commercial product, process, or service by trade name, trademark, manufacturer, or otherwise does not necessarily constitute or imply its endorsement, recommendation, or favoring by the United State Government or any agency thereof. The views and opinions of authors expressed herein do not necessarily state or reflect those of the United States Government or any agency thereof. 


\begin{abstract}
Solid oxide fuel cells (SOFC) hold great promise for clean power generation. However, high temperature stability and long term durability of the SOFC components have presented serious problems in SOFC technological advancement and commercialization. The seals of the fuel cells are the most challenging area to address. A high temperature gas seal is highly needed which is durable against cracking and gas leakage during thermal cycling and extended operation.

This project investigates a novel composite seal by integrating $3 \mathrm{D}$ printed shape memory alloy (SMA) wires into a glass matrix. The SMA we use is TiNiHf and the glass matrix we use is $\mathrm{SrO}-\mathrm{La}_{2} \mathrm{O}_{3}-\mathrm{Al}_{2} \mathrm{O}_{3}-\mathrm{B}_{2} \mathrm{O}_{3}-\mathrm{SiO}_{2}$ (SLABS). Dilatometry shows to be an extremely useful tool in providing the CTEs. It pinpoints regions of different CTEs under simulated SOFC thermal cycles for the same glass. For the studied SLABS glass system, the region with the greatest CTE mismatch between the glass seal and the adjacent components is $40-500^{\circ} \mathrm{C}$, the typical heating and cooling regions for SOFCs. Even for low temperature SOFC development, this region is still present and needs to be addressed. We have demonstrated that the proposed SLABS glass has great potential in mitigating the thermal expansion mismatch issues that are limiting the operation life of SOFCs. TiNiHf alloy has been successfully synthesized with the desired particle size for the 3DP process. The TiNiHf SMA shape memory effect very desirably overlaps with the problematic low CTE region of the glass. This supports the design intent that the gradient structure transition, phase transformation toughening, and self-healing of the SMA can be utilized to mitigate/eliminate the seal problem. For the 3DP process, a new binder has been identified to match with the specific chemistry of the SMA particles. This enables us to directly print SMA particles. Neutron diffraction shows to be an extremely useful tool in providing information regarding the austenite to martensite phase transformation, SMA alloy lattice constant change, and the corresponding thermal stress from the glass matrix. It pinpoints regions of SMA phase transformation and the thermal stress effect under simulated SOFC thermal cycles. The bilayer test shows that there is still much work to be done for the proper integration of the seal components. Large scale production should lower the cost associated with the proposed approach, especially on the raw material cost and 3D printing.
\end{abstract}




\section{Table of Contents}

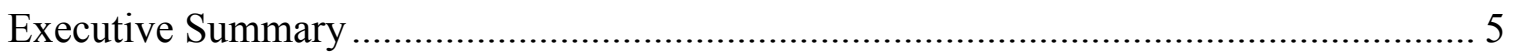

1.1) TiNiHf Alloy Powder Processing .................................................................. 7

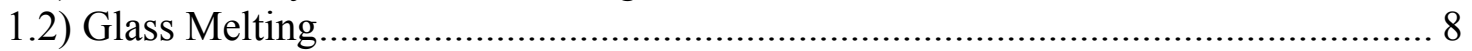

1.3) Thermal Expansion Coefficient Measurements ………........................................ 8

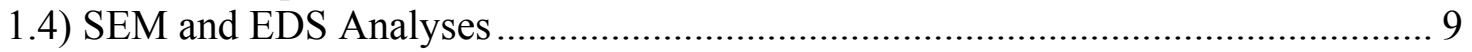

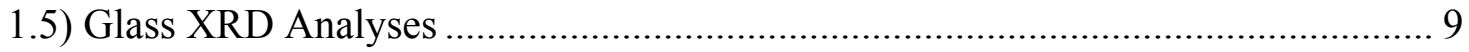

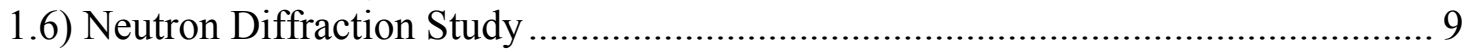

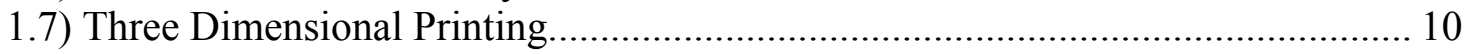

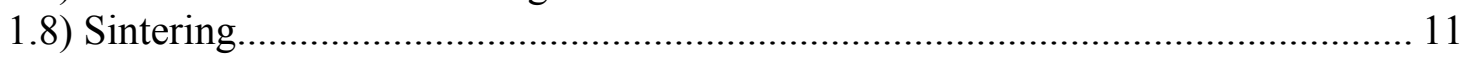

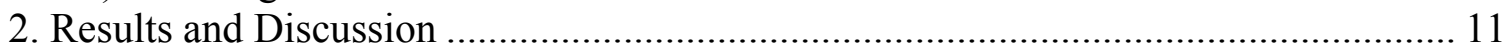

2.1) TiNiHf Alloy Microstructure Analysis............................................................ 11

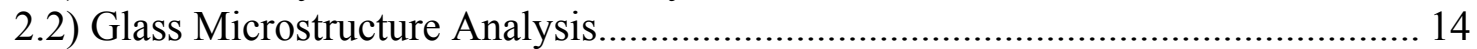

2.3) TiNiHf Alloy Shape Memory Effect Evaluation................................................... 15

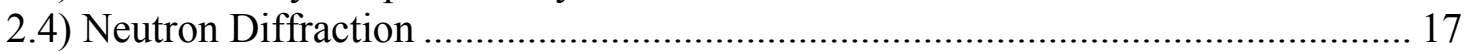

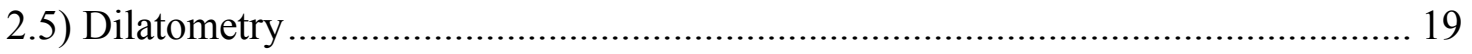

2.6) X-Ray Diffraction Pattern of SLABS Glass ........................................................ 22

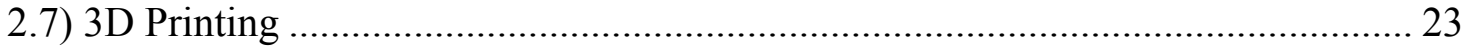

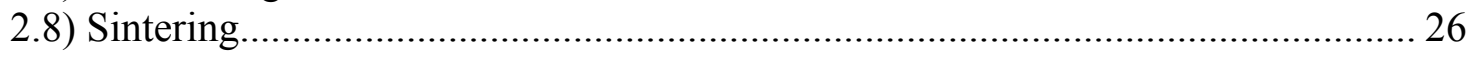

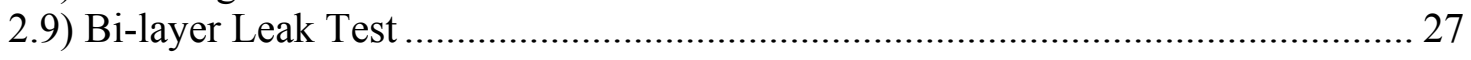

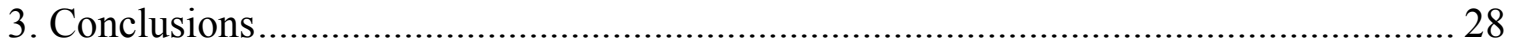

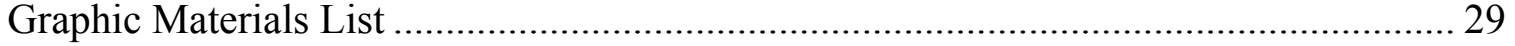

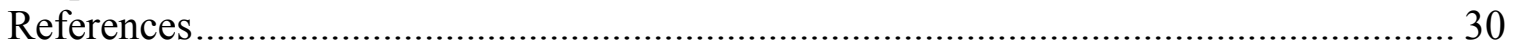

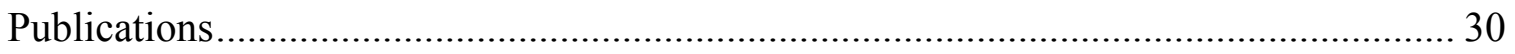




\section{Executive Summary}

Solid oxide fuel cells (SOFC) hold great promise for clean power generation. However, high temperature stability and long term durability of the SOFC components have presented serious problems in SOFC technological advancement and commercialization. The seals of the fuel cells are the most challenging area to address. A high temperature gas seal is highly needed which is durable against cracking and gas leakage during thermal cycling and extended operation. This project investigates a novel composite seal by integrating 3D printed shape memory alloy (SMA) wires into a glass matrix. The SMA we use is TiNiHf and the glass matrix we use is $\mathrm{SrO}-\mathrm{La}_{2} \mathrm{O}_{3}-\mathrm{Al}_{2} \mathrm{O}_{3}$ $\mathrm{B}_{2} \mathrm{O}_{3}-\mathrm{SiO}_{2}$ (SLABS).

TiNiHf has been successfully synthesized. The shape memory effect has been successfully achieved. Differential scanning calorimetry and microscopy have shown that the alloy has shape memory phase changes between 190 and $250^{\circ} \mathrm{C}$. However, TiNiHf milling has been proven to be a challenging task because of the ductility of the alloy. With these considerations, we gas atomized TiNiHf melt into $\sim 10 \mu \mathrm{m}$ particle sizes. The gas atomization approach allows us to adjust the TiNiHf alloy composition to the slightly higher Ni range. Also, we are able to obtain appropriate TiNiHf particle sizes for the three dimensional printing process while avoiding milling difficulties.

Several batches of $\mathrm{SrO}-\mathrm{La}_{2} \mathrm{O}_{3}-\mathrm{Al}_{2} \mathrm{O}_{3}-\mathrm{B}_{2} \mathrm{O}_{3}-\mathrm{SiO}_{2}$ glass have been synthesized to make cylindrical dilatometry samples and milled into powders for sintering around wire meshes. The dilatometry test shows that the coefficient of thermal expansion (CTE) for the glass between $40^{\circ} \mathrm{C}$ and $500^{\circ} \mathrm{C}$ is $7.02 \times 10^{-6} /{ }^{\circ} \mathrm{C}$; the CTE between $500^{\circ} \mathrm{C}$ and $700^{\circ} \mathrm{C}$ is $32.0 \times 10^{-6} /{ }^{\circ} \mathrm{C}$; and the CTE between 700 and $800^{\circ} \mathrm{C}$ is $21.4 \times 10^{-6} /{ }^{\circ} \mathrm{C}$. The overall CTE is

$13.9 \times 10^{-6} /{ }^{\circ} \mathrm{C}$. The dilatometry data highlight the fact that the CTE changes significantly with temperature. More importantly, it pinpoints regions of different CTEs under the same SOFC thermal cycle for the same material. For the studied SLABS glass system, the problematic region is $40-500^{\circ} \mathrm{C}$, the typical heating and cooling regions. Even for long term low temperature SOFC development, this region is still present. We have demonstrated the proposed SLABS glass has much higher CTE than the seal glasses used in the current SOFC research. This glass shows great potential in mitigating the thermal expansion mismatch issues that are hindering the long operation life of SOFC.

The TiNiHf SMA shape memory effect overlaps with the problematic low CTE region of the glass. This offers support for our assumption that the gradient transition, phase transformation toughening, and self-healing of the SMA can be utilized to mitigate/eliminate the seal problem.

Results on 3D printing have shown that the powder type and size, and the binder solution greatly affect the quality of the printed wire mesh structures. A 10-15 $\mu \mathrm{m}$ diameter powder is best for printing fine wire structures because it allows deposition of very fine layers $(25-50 \mu \mathrm{m}$ thick) while being still flowable during powder spreading. Coarser particles make it difficult to produce the wire features and finer particles do not flow uniformly during powder spreading.

In parallel, extensive work has been carried out for the optimization of the parameters of the three dimensional printing technique. Because of the thin mesh that we print, almost all the parameters need to be re-adjusted. Several different binders are 
evaluated to match with the new chemistry of the TiNiHf alloy. We have developed a new binder to impart very desirable high green strength to the thin TiNiHf mesh. As an additional improvement, binder curing after the 3DP process can be avoided.

Neutron diffraction is used to investigate the TiNiHf shape memory alloy phase transformation behaviors. The TiNiHf alloy slivers are embedded in a $\mathrm{SrO}_{-} \mathrm{SiO}_{2}$ glass matrix to determine if the thermal stresses arising from the glass matrix upon cooling affect the austenite to martensite phase transformation. It shows that the austenite to martensite phase transformation shifts to higher temperatures in the glass matrix. Also, the thermal expansion coefficient at the lattice level from the neutron diffraction matches well with the CTE measurement from the dilatometry. Neutron diffraction provides 0.001 $\AA$ measurement resolution for the TiNiHf alloy lattice parameter change during thermal cycling. The thermal expansion coefficient of the TiNiHf alloy measured at the lattice level from the neutron diffraction matches well with the thermal expansion coefficient measurement from the dilatometry.

The thermal expansion coefficients of commercial electrolyte $\left(\mathrm{Sc}-\mathrm{ZrO}_{2}\right)$ and interconnect (stainless steel) have been measured. These measurements provide quantitative data for further composite seal composition optimization.

Integration of the wire mesh and the SLABS glass has been attempted by simultaneous sintering of a metal mesh with glass powder. The design for bi-layer leak testing allows for control of temperature and internal pressure of the proposed composite sealed interconnect stainless steel and electrolyte $\mathrm{Sc}-\mathrm{ZrO}_{2}$ samples. There is still much work to be done for the proper integration of the seal components. Large scale production should lower the cost associated with the proposed approach, especially on the raw material cost and $3 \mathrm{D}$ printing. 


\section{Experimental Methods}

Solid oxide fuel cell (SOFC) seals have a demanding set of imposed performance criteria. Of particular importance is the ability to seal between metallic and ceramic components with differing coefficient of thermal expansion (CTE), and do so while being electrically isolating and exposed to temperature transients from room temperature to $650-950^{\circ} \mathrm{C}$. The fuel leakage rate should be $\leq 1 \times 10^{-6} \mathrm{~g} / \mathrm{cm} \cdot \mathrm{s}$ at $0.7 \mathrm{kPa}$ differential pressure. The seal material should have a service life of $>40,000$ hours and hundreds of thermal cycles for stationary systems or at least 5,000 hours and 3,000 thermal cycles for transportation systems. In this project, we use a three dimensional printing (3DP) technique to build a shape memory alloy (SMA) skeleton for the seal, use glass to fill the meshed SMA structure and transition into pure glass seal. The goal is to provide gradient CTE to reduce the thermal stress in the seal, further reduce the thermal stresses by SMA phase transformation toughening, and provide self-healing of the cracks in the glass matrix by SMA shape recovery during SOFC thermal cycling.

\section{1) TiNiHf Alloy Powder Processing}

TiNiHf SMA ingots were produced by arc-melting. Ti sponge (99.95\% purity, Alfa Aesar, Ward Hill, MA), Ni lump (99.99\% purity, Atlantic Equipment Engineers, Bergenfield, NJ), and Hf rod (99.95\% purity, Fine Metals Corporation, Ashland, VA) were melted in a water-cooled copper crucible under an argon atmosphere. Two ingots of 1.5 " $\mathrm{x} 3$ " $\mathrm{x} 0.5$ " in dimension were made with this procedure. The ingots were then homogenized in vacuum for 24 hours at $1075^{\circ} \mathrm{C}$ and then at $1150^{\circ} \mathrm{C}$ for 48 hours. The 1.5 " 3 " $\mathrm{x} 0.5$ " ingots were broken into approximately 0.5 " 0.5 " 0.5 " size pieces by cutting with a diamond wafer blade or by cutting a notch and hammering apart the pieces.

Milling of SMA powder was first attempted with a Spex Mill 8000 in a $50 \mathrm{~mL}$ Teflon bottle with alumina milling media. There was minimal fracture of the SMA pieces but excessive chipping of the alumina media was observed after 15 min of milling. From this observation, we believe that Spex milling may still be possible for creating a 10-15 $\mu \mathrm{m}$ powder but the SMA must be first broken down into small enough pieces before Spex milling can be effective. To further break down the TiNiHf alloy from 0.5 " 0.5 " 0.5 " size pieces into powders, TiNiHf pieces were frozen with liquid $\mathrm{N}_{2}$ to attempt to cool the alloy below a possible ductile-to-brittle transition temperature to induce brittle fracture. The efforts showed that this approach was not effective because the degree of brittleness achieved was not enough to allow fracture by the impact of a hammer under such temperature.

As the third approach, small pieces of SMA were cold rolled 4-6 times and cracking occurred through the thickness of the pieces. This approach successfully reduced the size of the SMA pieces and we were able to obtain small amount of SMA

powder. However, the process was inefficient. After these efforts, we tried cold rolling, jaw crushing, and pulverizing to break the large SMA pieces into micron size particles. However, none of these processes were proven to be effective. Also, incipient SMA melting during TiNiHf homogenization was shown by scanning electron microscopy, which we believe is due to a slightly low Ni concentration in the alloy. As a result, we used gas atomization to obtain different size particles and adjust the SMA composition to higher Ni content. 
The atomization was carried out at Crucible Research (Pittsburgh, PA) using a 50 lb. (nominal input) laboratory gas atomizer. The tilt-pour vacuum induction furnace was lined with an alumina crucible and coated with a proprietary combination of wash coats. The input materials were virgin metals including high-purity $(4 \mathrm{~N}+) \mathrm{Ni}$ and $\mathrm{Ti}$, plus $\mathrm{Hf}$ (99.95\% purity, Fine Metals Corporation, Ashland, VA). A portion of the raw materials was charged directly into the crucible and underwent a melt cycle and vacuum refining step. Late additions of raw materials were accommodated by four independent add hoppers. After the majority of the melting sequence, argon was introduced into the melt chamber to facilitate sampling, thermocouple immersion for temperature measurement, and equalization of the pressures in the melt and atomization (cooling) chambers. Preliminary chemical analysis was taken to confirm the composition as designed and final adjustment was made if necessary. After these steps, the melt was tilt poured into a refractory tundish fitted with a ceramic nozzle at the bottom.

The molten metal flew through the nozzle, which had a diameter of roughly $0.25 "$. When the melting alloy exited the nozzle, it was immediately introduced into a highpressure argon gas stream, delivered from an annular gas delivery die surrounding the nozzle bore. The commonly accepted model of gas atomization states that the melt stream is formed into a thin-walled cone (opening downwards) by the gas. As the cone expands, it thins and eventually breaks into ligaments (rubber band shaped rings of metal); these ligaments then break into smaller pieces under the influence of surface tension. The blobs of molten metal form into spheres and solidify while falling through the argon gas in the cooling tower, typically at $1000-10,000^{\circ} \mathrm{C} / \mathrm{s}$ (depending on particle size and other variables). We believe the process used for atomizing the TiNiHf alloy melt followed this sequence. The majority of the TiNiHf powder was collected in a pool of liquid argon (to prevent sintering), while finer particles were removed from the exhaust by a cyclone scrubber. After reaching room temperature, the powder was removed from the atomizer and passed through a 35 mesh screen to remove large and irregular particles. The scalped powder was then processed to -635 mesh (with an intermediate cut between 35 and 635 mesh) using a hand-fed ultrasonic screener.

\section{2) Glass Melting}

Several batches of $\mathrm{SrO}-\mathrm{La}_{2} \mathrm{O}_{3}-\mathrm{Al}_{2} \mathrm{O}_{3}-\mathrm{B}_{2} \mathrm{O}_{3}-\mathrm{SiO}_{2}$ oxides were mixed and Spex milled. After that the mixture was melted and poured directly from the melting temperature to make the proposed seal glass. The glass was melted at $1400^{\circ} \mathrm{C}$ and held at that temperature for 3 hours for homogenization. An alumina crucible was originally used for glass melting but the oxides in the glass reacted with the $\mathrm{Al}_{2} \mathrm{O}_{3}$ crucible at high temperature and caused the crucible wall to erode away, thus changing the composition of the glass. To avoid such problem, a platinum crucible was used for all glass melting and showed to be really successful.

\section{3) Thermal Expansion Coefficient Measurements}

For the CTE measurements, a push rod dilatometer (Orton 1600B, Edward Orton Jr. Ceramic Foundation, Westerville, Ohio) was used. Before measuring the CTEs of any SMA or glass, a fully dense alumina rod was measured twice as a standard sample to check the accuracy of the dilatometer itself. 
For the CTE measurement of the TiNiHf SMA, SMA sample of 1.093" long was used. The thermal profile was $5^{\circ} \mathrm{C} / \mathrm{min}$ heating and cooling rates, and the temperature range was from room temperature to $800^{\circ} \mathrm{C}$ to mimic the operation condition of actual SOFCs. The sample was thermally cycled twice.

To measure the CTEs of the SrO- $\mathrm{La}_{2} \mathrm{O}_{3}-\mathrm{Al}_{2} \mathrm{O}_{3}-\mathrm{B}_{2} \mathrm{O}_{3}-\mathrm{SiO}_{2}$ glass sample, we poured the glass melt into a graphite mold to make samples of 0.5 " diameter and 1 " long. The resultant glass samples had an opaque glass core with a cracked but clear glass shell that was about $1 \mathrm{~mm}$ thick. Inside the clear layer the sample was dense and appeared to be uniform. For the dilatometer measurement, the push rod was positioned in the dense opaque region and we believe the CTEs thus obtained reflect the thermal behavior of the bulk glass. Also, the measurements were obtained for four consecutive thermal cycles to obtain representative data for CTEs and observe the thermal behavior of the glass under thermal cycling. Again, the thermal profile for all the CTE measurements was $5^{\circ} \mathrm{C} / \mathrm{min}$ heating and cooling rates, the temperature range was from room temperature to $800^{\circ} \mathrm{C}$.

We obtained commercial SOFC electrolyte, Sc-stabilized $\mathrm{ZrO}_{2}$, from Ceramatec (Salt Lake City, Utah) and the stainless steel interconnect from ATI Allegheny Ludlum (Pittsburgh, PA) under the trade name E-Brite. We used $3{ }^{\circ} \mathrm{C} / \mathrm{min}$ heating and cooling rates, $\mathrm{RT}-800^{\circ} \mathrm{C}$ for the $\mathrm{ZrO}_{2}$ electrolyte and the stainless steel interconnect $\mathrm{CTE}$ measurements.

\section{4) SEM and EDS Analyses}

The as-is surface and the interior of the SMA and the glass were examined by a field emission scanning electron microscopy (SEM) (Carl Zeiss MicroImaging, Inc, Thornwood, NY). The composition analyses of the SMA and the glass were carried out using the energy dispersive X-ray spectroscopy (EDS) on the field emission SEM by identifying locations of interest and correlating the composition with the morphology of the specific locations.

\section{5) Glass XRD Analyses}

The as-cast SLABS glass was thermally cycled four times to $800^{\circ} \mathrm{C}$ at $10^{\circ} \mathrm{C} / \mathrm{min}$ and no cracks were visible after cycling; also, the clear glass layer disappeared from the outer shell. Crystalline phase identification of the as-cast and thermally cycled SLABS glass was conducted by X-ray powder diffraction (XRD) on a Rigaku X-ray diffractometer using $\mathrm{Cu} \mathrm{K} \alpha$ radiation.

\section{6) Neutron Diffraction Study}

Slivers of TiNiHf alloy approximately $1 \mathrm{~mm} \times 1 \mathrm{~mm} \times 20 \mathrm{~mm}$ in size were cut from the bulk of an ingot that was produced by arc-melting under vacuum. The glass used in the neutron diffraction study was adjusted to avoid boron (boron is a strong neutron absorbing material and hinders neutron diffraction) and the composition was $35 \mathrm{SrO}-$ $65 \mathrm{SiO}_{2}$. For $\mathrm{SrO}-\mathrm{SiO}_{2}$ synthesis, 50 grams of $35 \mathrm{SrO}-65 \mathrm{SiO}_{2}$ were ball milled with $\mathrm{Al}_{2} \mathrm{O}_{3}$ media for homogeneity. The mixture was then melted at $1675^{\circ} \mathrm{C}$ in a Pt crucible and poured into a $15 \mathrm{~mm}$ diameter by $10 \mathrm{~mm}$ length graphite mold. The graphite mold contained five SMA slivers supported by holes in the base of the mold. Since cracks were observed for the integrated SMA/glass samples, they were annealed by heating and cooling at $10^{\circ} \mathrm{C} / \mathrm{min}$ to $850^{\circ} \mathrm{C}$ with no hold. After annealing, the cracks were healed and 
the glass changed color from clear to slightly opaque. Figure 1 is the SMA/glass sample after annealing. A glass cylinder was also poured into the mold with no SMA slivers and annealed with the same thermal profile.

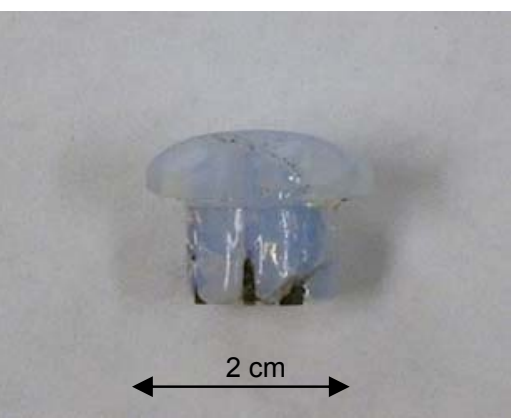

Figure 1. SMA / glass sample for neutron diffraction.

The SMARTS system in the Lujan Center at Los Alamos National Laboratory, NM was used for neutron diffraction. Samples were placed free standing on a graphite base in the chamber of a vacuum furnace. They were heated at $15^{\circ} \mathrm{C} / \mathrm{min}$ to $800^{\circ} \mathrm{C}$ and then cooled at different rates.

The glass/SMA sample was cooled first at $5^{\circ} \mathrm{C} / \mathrm{min}$ to $375^{\circ} \mathrm{C}$ and then held for approximately 30 minutes to achieve a neutron detection count of $1.5 \times 10^{3} \mathrm{Ah}$. The sample was then cooled in $10^{\circ} \mathrm{C}$ and $20^{\circ} \mathrm{C}$ steps at $5^{\circ} \mathrm{C} / \mathrm{min}$ for more $1.5 \times 10^{3} \mathrm{Ah}$ diffraction patterns. The same glass/SMA sample was heated again to $800^{\circ} \mathrm{C}$ and then cooled at $30^{\circ} \mathrm{C} / \mathrm{min}$ to a first diffraction temperature of $350^{\circ} \mathrm{C}$ and cooled in $25^{\circ} \mathrm{C}$ and $10^{\circ} \mathrm{C}$ steps. A similar temperature profile was conducted on the SMA slivers without glass, with the exception that the cooling rate was at $15^{\circ} \mathrm{C} / \mathrm{min}$. The detailed neutron diffraction study at $\mathrm{RT}-350^{\circ} \mathrm{C}$ range was based on the SMA phase transformation temperatures obtained from the differential scanning calorimetry results. It should be pointed out that there was difficulty in accurately controlling the cooling rate at such low temperatures. This is because the furnace was evacuated and heat transfer was only through conduction through the graphite base. However, at present there is not an ideal furnace set-up that can provide accurate cooling at such low temperatures while can still be heated to $800^{\circ} \mathrm{C}$, which is the expected operation temperature for SOFCs.

\section{7) Three Dimensional Printing}

The 3DP technique is a unique process being commercialized by Ex-One (Irwin, PA). The equipment used for this program was the RX-1 model. The technique started with dry powders and created parts in layers from a CAD model. The solid model, formatted into a .stl file (standard triangle language), was converted by a slicing routine into a compilation of two-dimensional slices representing the three-dimensional part. The slice file was further formulated into instructions that controlled the movement of the 3DP machine components. During the 3D printing, each layer began with a thin distribution of powder. The powder was spread by a counter-rotating roller onto a build platform inside a build box. Then a printhead, containing an array of binder fluid jets, rastered across the layer of the powder and deposited binder droplets in those locations defined by the current 2D slice of the solid model. The build platform advanced downward by one layer thickness and a new layer of powder was spread, which was then 
printed by the printhead. This procedure was repeated layer after layer until the 3D part was completed.

The minimum feature size that can be printed is determined by the binder droplet size and is typically $50 \mu \mathrm{m}$ for the thickness and $200 \mu \mathrm{m}$ for the disk diameter. The 3DP process can create parts of any geometry; the support gained from the powder bed enables open pores, closed pores, channels, or any combinations of these features. It can also create very well controlled "unmachinable" geometry such as overhangs, undercuts, and internal volumes, or stack and nest multiple parts within the build chamber. This solid freeform fabrication technology has demonstrated the capacity of fabricating parts of a variety of materials, including ceramics, functionally graded materials, and tool steels with an array of unique geometries, including intricate internal passage similar to the cooling passages in turbine blades.

In this project, the 3DP process served as a key technique in printing the SMA meshes. Since the technique was newly applied to the TiNiHf system, the printing parameters and the binders all needed to be re-examined.

\section{8) Sintering}

The glass making process showed that sintering the glass powder and the printed SMA wire mesh is a more feasible approach than pouring the glass melt directly into the SMA wire mesh for integrating the SMA and the glass. Subsequently, a composite seal was made by infiltrating a TiNi wire mesh with the proposed SLABS glass powder and sintering the composites. The glass was first melted and quenched into water and then Spex milled to create a fine powder. The TiNi wire mesh of $500 \mu \mathrm{m}$ wire thickness was 3D printed, dried, and placed in a rectangular alumina crucible. The glass powder was then sprinkled around the wire mesh to fill the wire mesh. The binder removal and sintering cycle was $5^{\circ} \mathrm{C} / \mathrm{min}$ heating rate from room temperature to $500^{\circ} \mathrm{C}, 2 \mathrm{hr}$ dwell at $500^{\circ} \mathrm{C}, 5^{\circ} \mathrm{C} / \mathrm{min}$ heating rate to $950^{\circ} \mathrm{C}, 5 \mathrm{hr}$ dwell at $950^{\circ} \mathrm{C}$, and cooling to room temperature at $5^{\circ} \mathrm{C} / \mathrm{min}$. The purpose was to first remove the binder by thermal decomposition and then sinter the glass around the wire mesh. The thermal process was carried out in an alumina tube furnace (CM Furnaces, Inc. Bloomfield, New Jersey) while flowing high purity argon gas.

\section{Results and Discussion}

\section{1) TiNiHf Alloy Microstructure Analysis}

Figure 2 is a scanning electron microscopy image of the surface of the as-melted TiNiHf SMA. Dendrite formation and microsegregation are found in the ingot, which suggests that the alloy composition is slightly off the targeted congruent melting composition. The presence of dendrites indicates that the alloy is not entirely homogeneous. EDS analysis shows the as-cast ingots to be Ni deficient and Ti rich on the surface, which is attributed to the evaporation of a small amount of Ni during arcmelting. The ingot surface also has some oxygen contamination (Figure 3). It should be pointed out that EDS is a qualitative chemical analysis technique and the results in Figure 3 are used to confirm the absence of gross macrosegregation rather than as a quantitative chemical analysis. Figure 4a shows the optical images of the same as-melted SMA alloy 
in cross-section. Using differential interference contrast in the optical microscope, the plate-like structure of martensite can be seen. Also, there are some unidentified precipitates in the region with a martensite structure (Figure 4b). Both the microsegregation associated with the dendrites and the second phase precipitates could impede the reversibility of the martensite reaction, so the as-melted SMA is homogenized to improve the shape memory effect of the alloy.

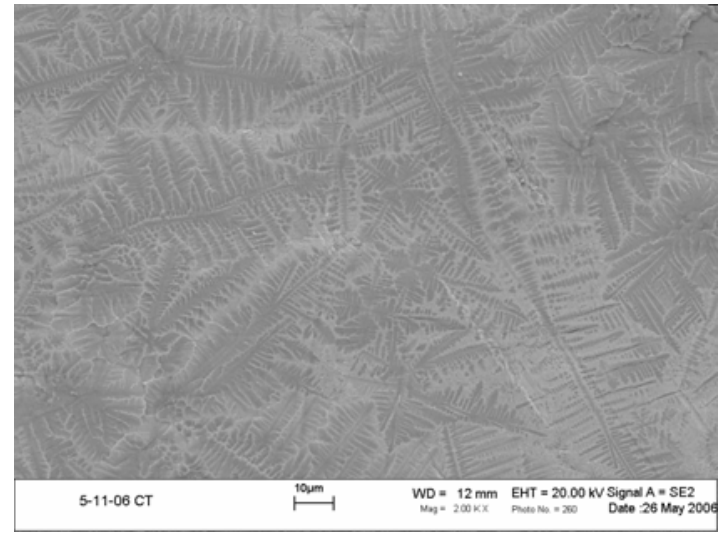

Figure 2. SEM image of the dendrites on the surface of as-melted TiNiHf shape memory alloy.

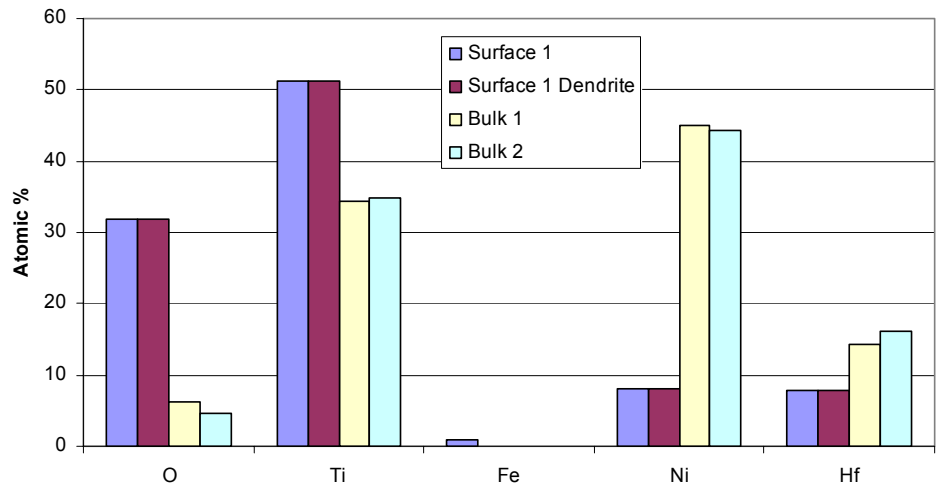

Figure 3. EDS analysis of the compositions on the surface and in the bulk of the as-melted TiNiHf shape memory alloy.

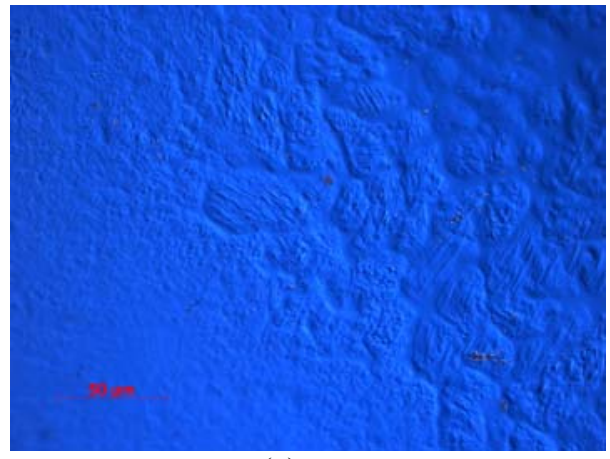

(a)

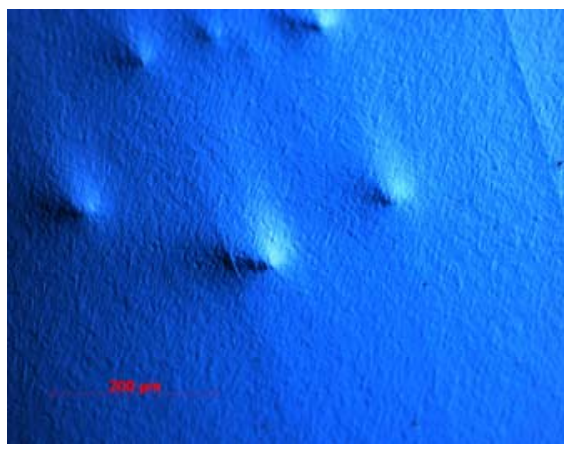

(b)

Figure 4. Optical micrograph of as-melted SMA showing martensite plates within dendrites in (a), martensite and second-phase precipitates in (b). 
After homogenization, fully martensitic microstructure was seen in the bulk of the ingot (Figure 5a), but there is a $\sim 1 \mathrm{~mm}$ thick surface layer that is only partially martensite. The lower half of Figure $5 \mathrm{~b}$ is the bulk of a homogenized piece of SMA, while the top half of Figure $5 b$ is the region near the surface that has a more complex microstructure. The homogenization has been carried out in evacuated quartz tubes. It is likely that some of the quartz is reduced by the SMA alloy during the homogenization treatment and the resulting oxygen from the tube is able to diffuse into the outer region of the alloy pieces. After homogenization, the shape memory effect is clearly observed in the SMA samples taken from the bulk, but not in the samples taken near the surface of the ingot. To prevent the undesirable impact of the outer surface layer on the shape memory effect, the surface non-martensitic region has been ground off before cold rolling. During SEM analysis, we have also identified a small amount of incipient melting phase, which confirms the ingot composition is slightly off the congruent composition and slightly Ni-poor. This is probably caused by the evaporation of some $\mathrm{Ni}$ during arc-melting and a resulting shift of the ingot composition into a solid + liquid phase field at the homogenization temperature (Figure 6). EDS analysis of the small melted regions in the homogenized SMA shows higher Ti content (Figure 7a) and the solid phase in the bulk of the sample shows lower Ti content (Figure 7b). Quantitative analysis of the SEM micrographs indicates that melted phase accounts for about $8.5 \mathrm{vol} \%$ of the total. The shape memory effect is clearly obtained in the TiNiHf SMA alloy over a desirable temperature range. For the atomized TiNiHf alloy, chemical analysis has been carried out. As desired, the atomic percent of $\mathrm{Ni}$ increased by $1 \%$ in comparison to the arc-melted TiNiHf composition.

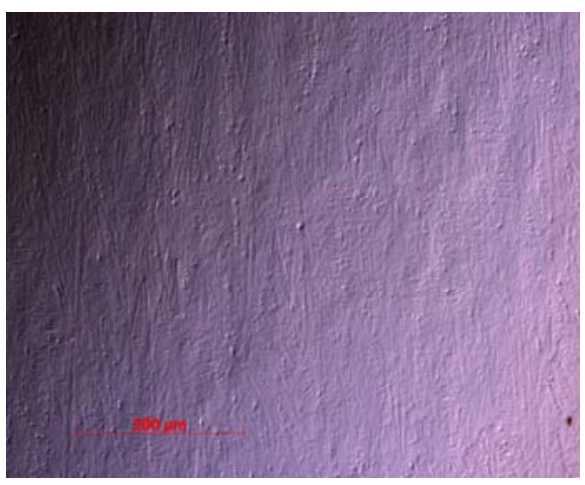

(a)

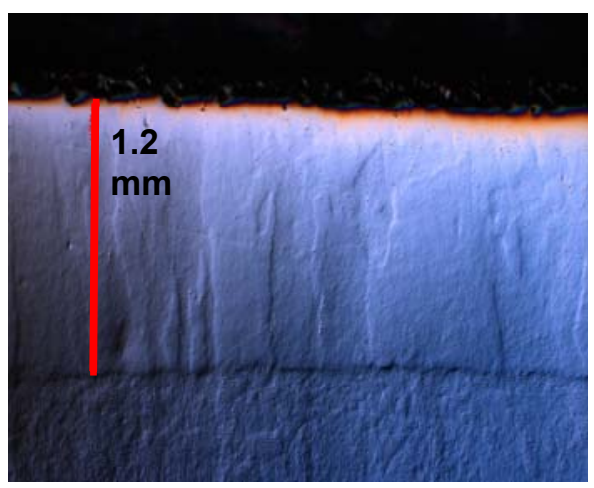

(b)

Figure 5. Optical micrograph of homogenized SMA showing pure bulk martensite phase after homogenization (a), and surface layer with non-martensite phase and the bulk with martensite phase (b). 


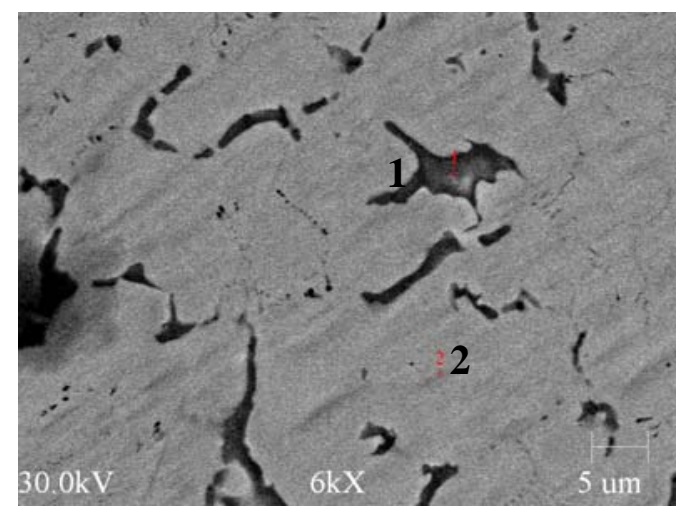

Figure 6. SEM micrograph of homogenized SMA showing regions that melted during homogenization (dark regions) and solid phase (gray regions) in the bulk of the sample. The marked locations 1 and 2 are for EDS analysis shown in Figure 7.

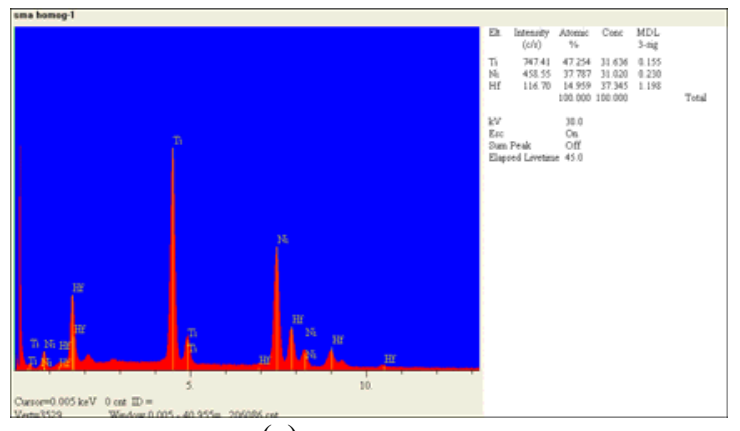

(a)

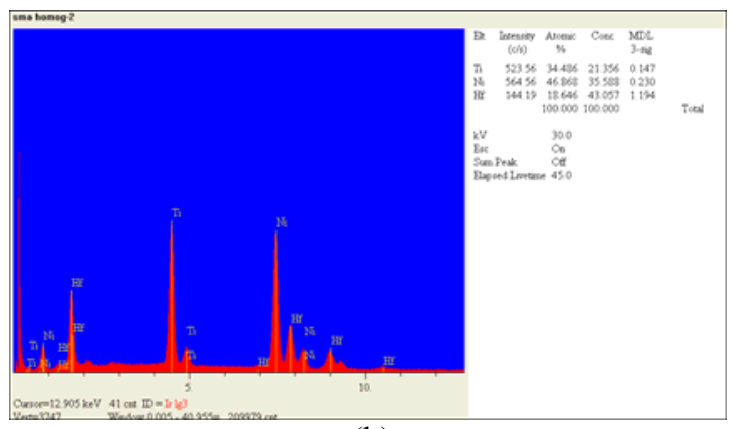

(b)

Figure 7. EDS analysis of homogenized SMA showing melted pockets (location 1 in Figure 6) has higher Ti content (a) and the solid phase (location 2 in Figure 6) has lower Ti content (b).

\section{2) Glass Microstructure Analysis}

As stated previously, two approaches have been used to quench the glass after high temperature melting. One quenches the glass melt directly into room temperature water and the other quenches the glass melt into a graphite mold. Because of heat transfer to water is higher than to graphite, different kinds of glass have been obtained. For the water quenched glass, the bulk is clear. For the graphite quenched glass, there is a clear glass layer on the outer surface of the sample; but the bulk glass is opaque. Preliminary SEM analysis indicates that both kinds of glass are likely amorphous (Figure 8). 


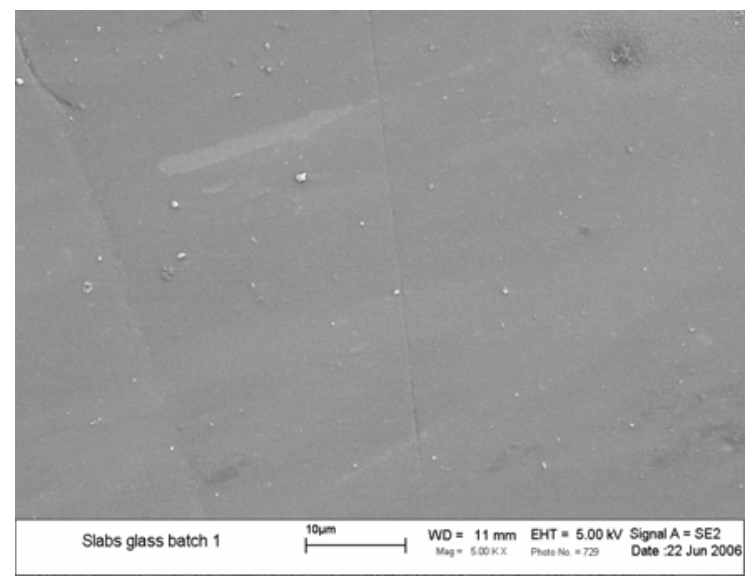

(a)

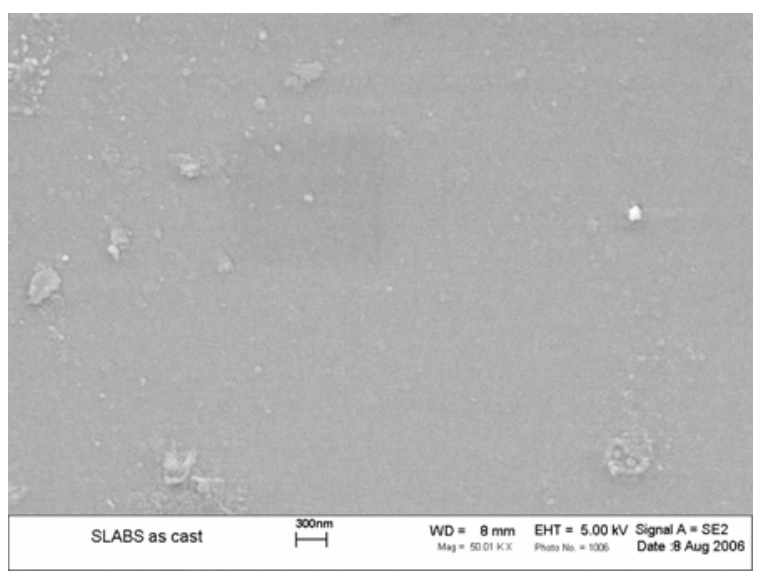

(b)

Figure 8. Microstructures of the SLABS glass produced by quenching the glass melt directly into water at room temperature (a), and quenching into a graphite mold (b).

SEM images of the fractured surface for the graphite mold quenched glass are shown in Figure 9a without any thermal cycle and in Figure $9 \mathrm{~b}$ after four thermal cycles. The thermal cycle is $5^{\circ} \mathrm{C} / \mathrm{min}$ heating rate to $800^{\circ} \mathrm{C}, 0$ dwell time, and cool down to room temperature at $5^{\circ} \mathrm{C} / \mathrm{min}$. For Figure $9 \mathrm{a}$ as-quenched glass, there are cracks on the outer layer. For the thermally cycled glass the cracks tend to heal themselves and the fracture surface seems to be still amorphous after the thermal cycling. EDS results show that there might be a $\mathrm{La}_{2} \mathrm{O}_{3}$ rich phase for the graphite-mold quenched glass and the correspondingly thermal-cycled glass. Correlating the SEM results with the CTE measurements to be discussed next, we believe the new phase can play a role in affecting the CTE of the glass.

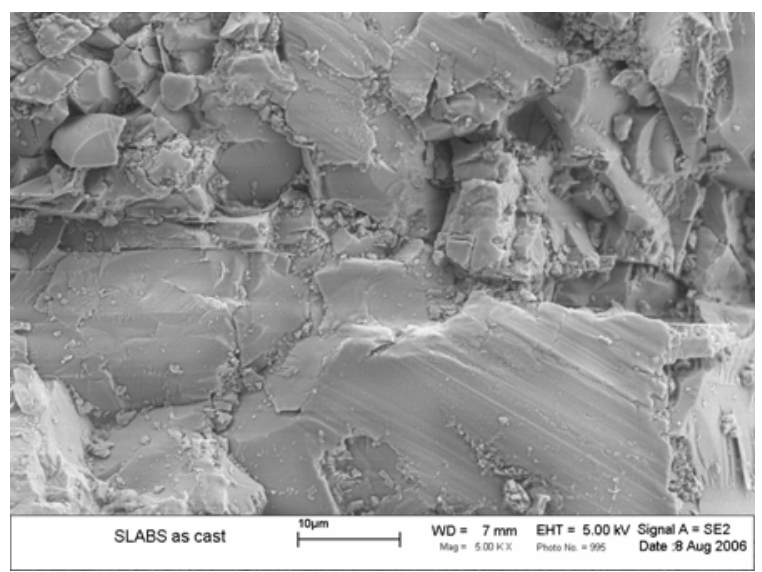

(a)

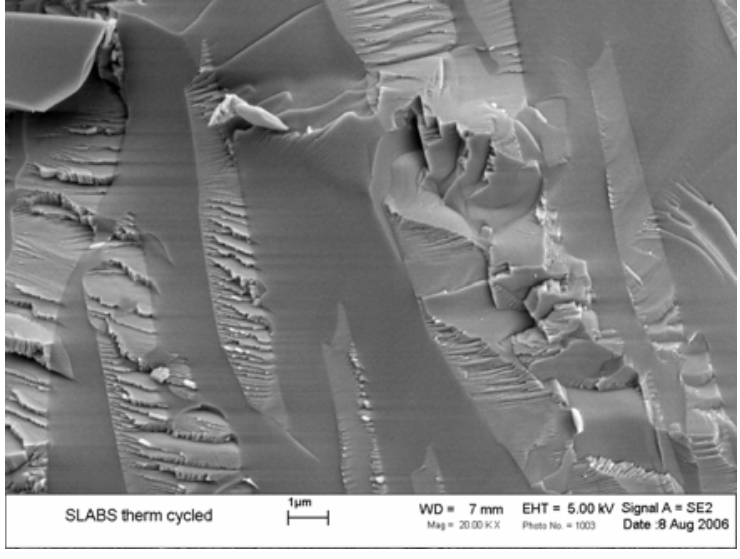

(b)

Figure 9. Microstructures of the SLABS glass produced by quenching the glass melt directly into a graphite mold. (a): as-quenched, (b) after four thermal cycles.

\section{3) TiNiHf Alloy Shape Memory Effect Evaluation}

Differential Scanning Calorimetry (DSC) is a characterization method that measures the effective heat capacity in small (10-20 mg) samples. The shape memory effect in TiNiHf SMA occurs because of an austenite $\leftrightarrow$ martensite phase change over a specific temperature range. During the phase change, the SMA absorbs heat or gives off 
heat and the DSC is capable of detecting the transformation by measuring the changes in heat content. To achieve self-healing and transformation toughening abilities of the system, it is important to verify with DSC the temperature range over which the shape memory effect occurs. The transition should take place in the range that will be useful for healing the glass seal.

In this research, DSC measurement of the as-cast SMA does not show shape memory behavior (Figure 10). As shown in Figures 5 and 6, the undesired phases present in the as-melted SMA are apparently preventing the shape memory effect. After the SMA is homogenized, the edge of the sample again does not show any shape memory effect, but the bulk of the sample shows strong peaks at austenite $\leftrightarrow$ martensite phase transition temperatures as seen in Figure 11. Thermal cycling increases the shape memory effect (DSC peak height shifts and becomes sharper as the number of thermal cycles increases a characteristic of shape memory alloys called "training"). The SMA martensite start temperature is $196^{\circ} \mathrm{C}\left(\mathrm{M}_{\mathrm{s}}\right)$ and the finish temperature is $188^{\circ} \mathrm{C}\left(\mathrm{M}_{\mathrm{f}}\right)$ and the austenite start temperature is $234^{\circ} \mathrm{C}\left(\mathrm{A}_{\mathrm{s}}\right)$ and the finish temperature is $248^{\circ} \mathrm{C}\left(\mathrm{A}_{\mathrm{f}}\right)$.

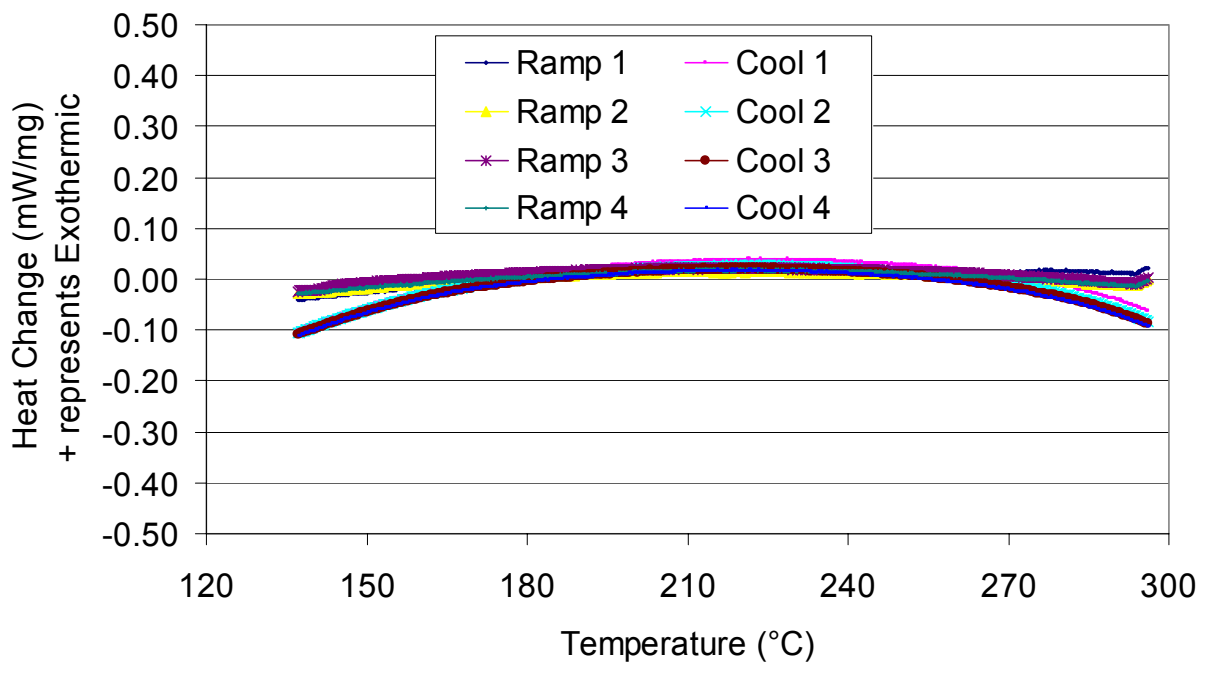

Figure 10. Differential scanning calorimetry of as-melted shape memory alloy showing no shape memory effect.

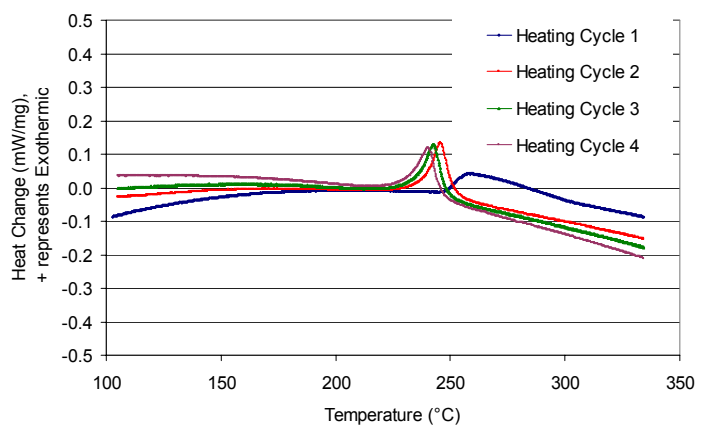

(a)

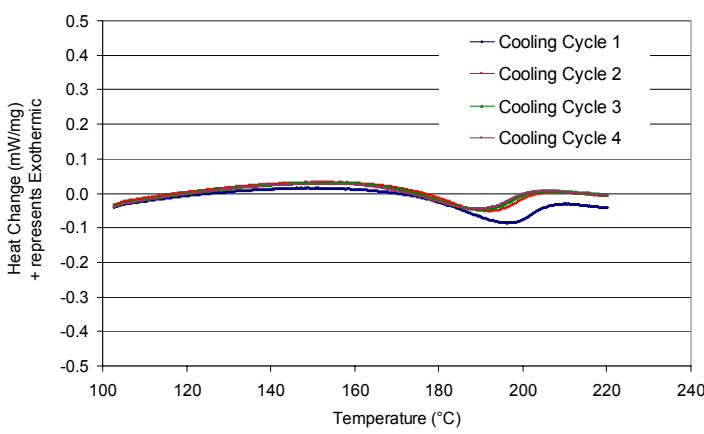

(b)

Figure 11. Differential scanning calorimetry of homogenized shape memory alloy showing shape memory effect during heating (a) and cooling (b) cycles. (a) shows the austensitic phase transformation start and finish temperatures, and (b) shows the martensitic phase transformation start and finish temperatures. 


\section{4) Neutron Diffraction}

Figure 12 is a neutron diffraction pattern during the austenite to martensite transition. The thick arrow points to the austenite (110) peak while the dotted arrow points to a martensite double peak. The d-spacing and intensity of these peaks were analyzed. The background noise was from glass scattering. Diffraction of annealed pure glass was conducted to ensure that no ceramic crystalline peaks were confounding the data. As shown in Figure 12, the martensite peak was barely visible at $180^{\circ} \mathrm{C}$. As the temperature was decreased to $162^{\circ} \mathrm{C}$ and $124^{\circ} \mathrm{C}$, the martensitic (101) and $(020) /(012)$ double peak intensity kept increasing, indicating the austenite to martensite phase transformation process ((020) and (012) peaks locate on the right side of the double peak but are too close to be resolved).

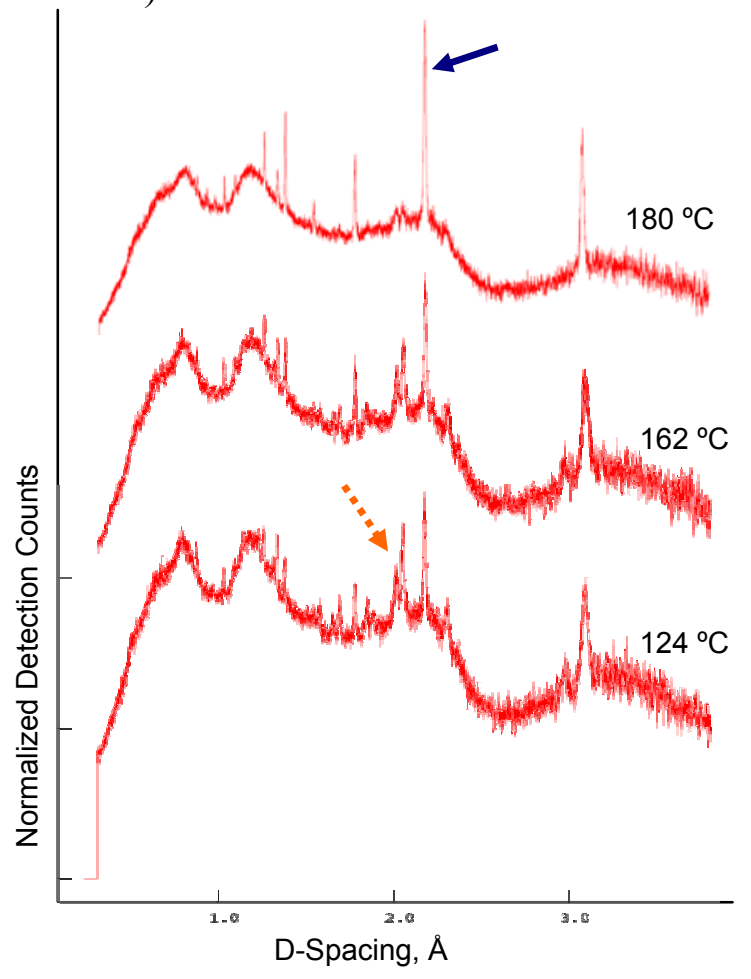

Figure 12. Neutron diffraction pattern from the SMA/glass sample at $180^{\circ} \mathrm{C}, 162^{\circ} \mathrm{C}$, and $124^{\circ} \mathrm{C}$. Solid arrow points to austensitic (110) peak and dotted peak points to martensitic (101) and (020)/(012) double peak.

Normalized (110) austenite peak intensity is plotted in Figure 13 for the three diffraction tests: $\mathrm{SMA} / \mathrm{glass}$ cooled at $5^{\circ} \mathrm{C} / \mathrm{min}, \mathrm{SMA} / \mathrm{glass}$ cooled at $30^{\circ} \mathrm{C} / \mathrm{min}$, and SMA cooled at $15^{\circ} \mathrm{C} / \mathrm{min}$. The neutron intensity was normalized based on the first detection, which is at $350^{\circ} \mathrm{C}$. After the austenite to martensite phase transformation, there is still $\sim 30 \%$ retained austenite. With the notion that the temperature control may not be very precise, there is an observable shift to lower temperatures for the phase transformation without glass matrix. Qualitatively, this demonstrates that the glass matrix constrained SMA phase transformation occurs at higher temperatures, which means the SMA absorbs the thermal stress in the glass matrix as designed. This means the shape 
memory effect can be utilized to absorb the thermal energy in the glass matrix generated by the thermal stress and provide phase transformation toughening.

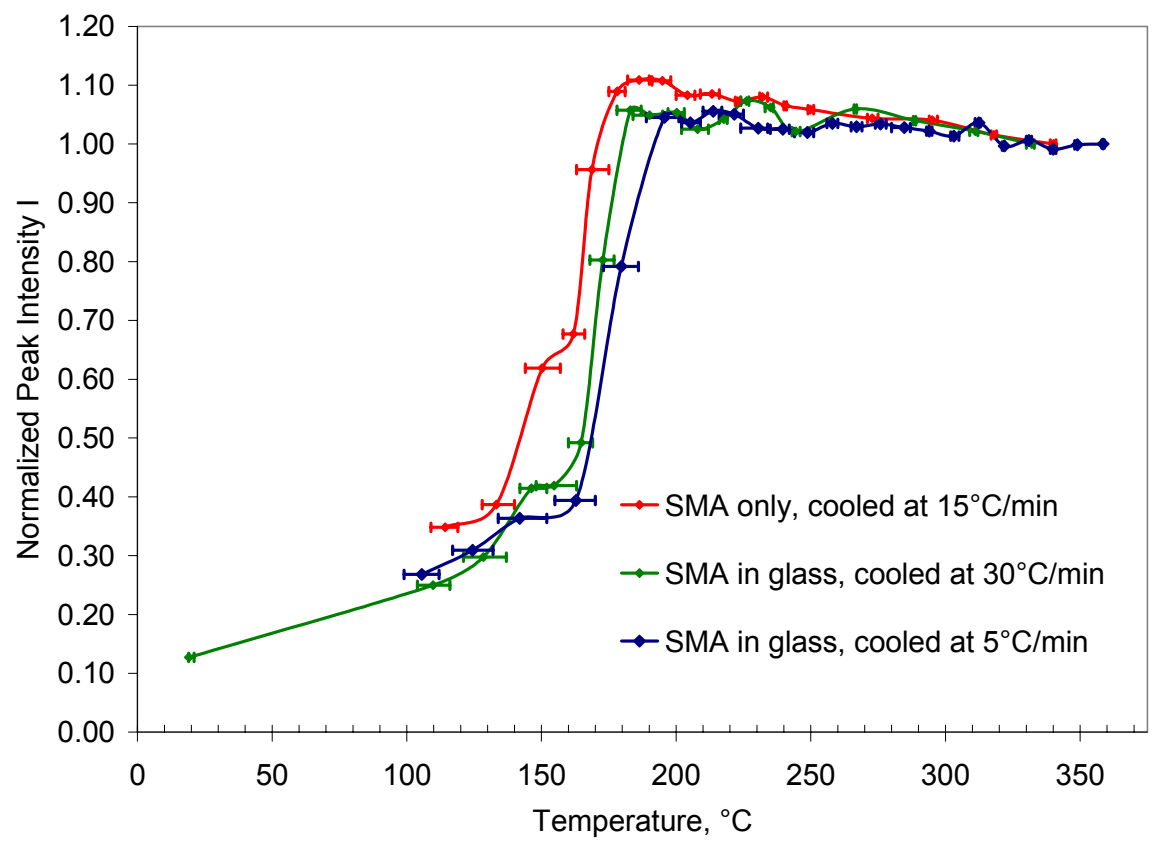

Figure 13. Peak intensity for the (110) austenite peak during cooling.

D-spacing of the (110) austenite peak is plotted in Figure 14 for the three samples at different temperatures. The (110) d-spacing for the SMA alloy without glass is approximately $0.001 \AA$ higher than that in glass during cooling above the martensitic transition. The curves are identical for the slow cooled and fast cooled SMA/glass samples and are both parallel to that of the SMA sample. The SMA slivers were held in a $\mathrm{Nb}$ crucible and there is a $\mathrm{Nb}$ peak $0.1 \AA$ to the right of the (110) peak which could have caused the shift. Analysis of the (110) peak was refined to a smaller interval but the dspacing still remained exactly at the same positions indicating that the $\mathrm{Nb}$ peak did not affect the (110) d-spacing analysis. Also, the samples came from two identical ingots and the diffraction peaks are the average of five SMA slivers in the sample. The slivers were randomly chosen from several locations of the two ingots, so it is unlikely that a chemistry difference could cause such a change in d-spacing. The only likely cause is thermal stress induced phase transformation change. However, there is one aspect that cannot be explained. The thermal stresses from the glass should increase the SMA dspacing because the metal has a higher CTE and tends to shrink more during cooling. Under the constraint of the glass matrix, the SMA should be 'pulled' instead of being 'squeezed'. The (110) plane should be in tension and thus demonstrates larger d-spacing, opposite to what was observed in Figure 14. It is possible that the glass matrix has phase change that is not visible from the neutron diffraction pattern. The full strain tensor can not be computed from the current neutron diffraction data. More elaborate experiments tracking different pre-compressed/pulled directions of the SMA alloy can probably help to explain this. 


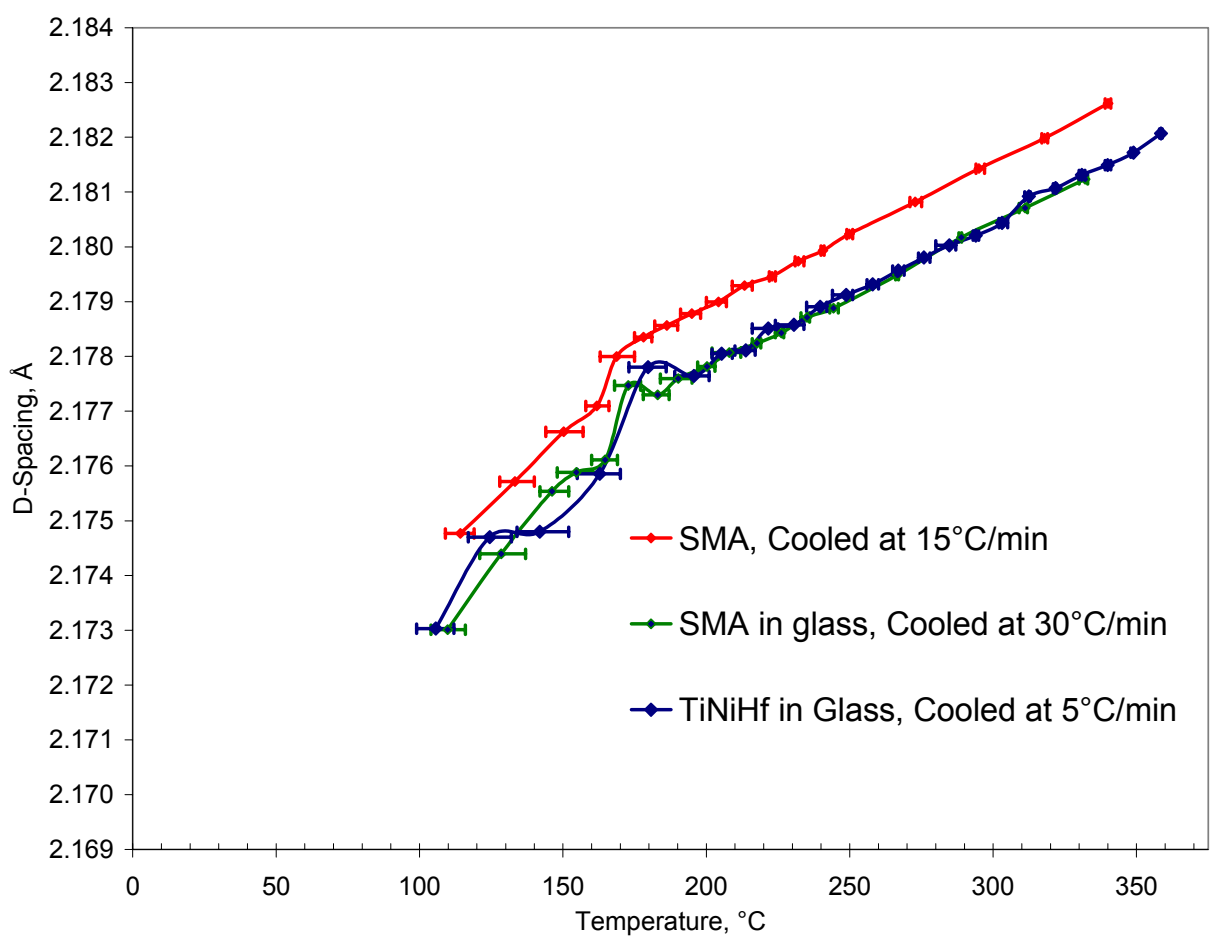

Figure 14. D-spacing of the (110) austenite peak during cooling.

The SMA/glass sample shows erratic changes in d-spacing at the onset of the martensitic transformation, observable as bumps in Figure 15. For the NiTi system, the R phase is observed as an intermediate monoclinic phase between the cubic austenite and the martensite. However, it is not observed near 50Ni-50Ti region. Since Hf replaces Ti in the cubic structure, the TiNiHf alloy is unlikely to show a $\mathrm{R}$ phase. Also, no monoclinic peaks are observed from the neutron diffraction during cooling. The erratic changes in d-spacing could be an interaction between the external stress from the glass matrix and the extra stress from the SMA during the shape memory phase transformation.

The D-spacing of the austenite (110) peak shows a linear change with temperature up to the martensitic phase transformation starting temperature (Figure 15). The slope of the curve above the martensitic phase transformation starting temperature is $2.6 \times 10^{-5}$ $\AA /{ }^{\circ} \mathrm{C}$. An estimate of coefficient of thermal expansion $(\alpha)$ can be calculated based on $\alpha=(1 / \mathrm{a}) *(\mathrm{da} / \mathrm{dT})$. For the SMA at above the martensitic phase transformation starting temperature, $\alpha \approx 12.1 \times 10^{-6} /{ }^{\circ} \mathrm{C}$. This is close to the value measured for the bulk SMA of $16.9 \times 10^{-6} /{ }^{\circ} \mathrm{C}$ in consideration of the grain boundaries, defect, and other non-ideal microstructures.

\section{5) Dilatometry}

As indicated, a fully dense alumina rod has been measured as a standard sample to check the accuracy of the dilatometer itself. For the first run, the CTE is $8.6 \times 10^{-6} / \mathrm{K}$ from room temperature to $1600^{\circ} \mathrm{C}$. For the second run, the CTE is $8.47 \times 10^{-6} / \mathrm{K}$ from room temperature to $1600^{\circ} \mathrm{C}$. These values are very consistent with the literature values for alumina [1]. This gives us assurance that the CTE measurements for the SMA and the SLABS glass will be dependable. 
Figure 15 is the CTE curve of the heating segments for the glass during the dilatometry test. During the first heating cycle, the sample shows a negative slope at $\sim 650^{\circ} \mathrm{C}$. This is believed to be from the shrinkage of the sample when the outer glass layer changes to a more stable opaque phase, which is supported by the glass color change. When the glass is removed from the dilatometer, the clear surface shell has turned into the same opaque color as the bulk glass and it is not possible to distinguish between the sample outer layer and the core of the sample. When the dimensions at the starting point of each thermal cycle are used as the comparison basis and the CTE is averaged for the three thermal cycles after the first one, the CTE between $40^{\circ} \mathrm{C}$ and $500^{\circ} \mathrm{C}$ is $7.02 \times 10^{-6} /{ }^{\circ} \mathrm{C}$; the CTE between $500^{\circ} \mathrm{C}$ and $700^{\circ} \mathrm{C}$ is $32.0 \times 10^{-6} /{ }^{\circ} \mathrm{C}$; and the CTE between 700 and $800^{\circ} \mathrm{C}$ is $21.4 \times 10^{-6} /{ }^{\circ} \mathrm{C}$. The overall $\mathrm{CTE}$ is $13.9 \times 10^{-6} /{ }^{\circ} \mathrm{C}$.

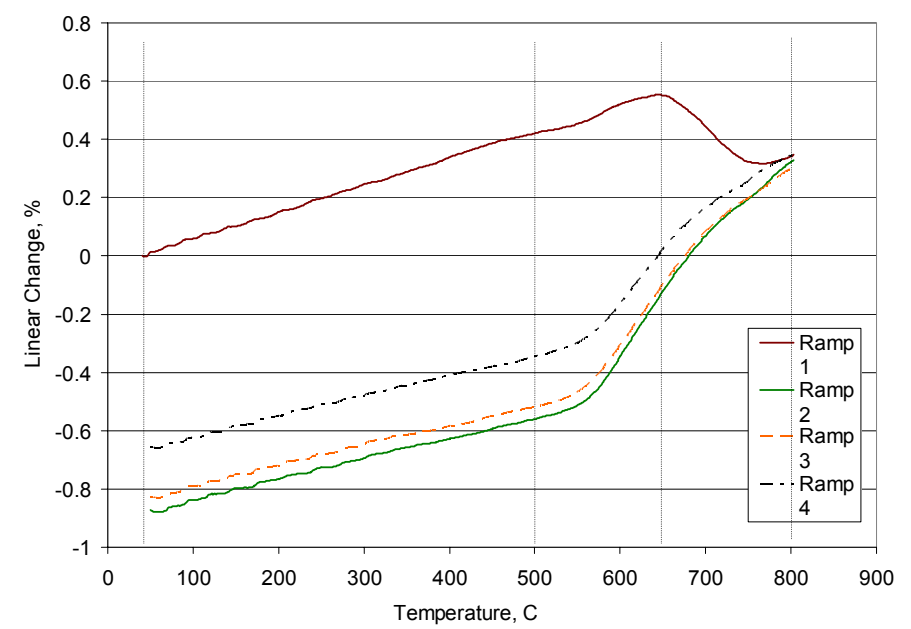

Figure 15 . Dilatometry test of the SLABS glass CTE under $5^{\circ} \mathrm{C} / \mathrm{min}$ heating/cooling rates.

As we know, the CTEs of the current SOFC materials are $\mathrm{Ni} / \mathrm{ZrO}_{2}$ anode: $12.5 \times 10^{-6} / \mathrm{K}$; doped $\mathrm{LaMnO}_{3}$ cathode: $11.0 \times 10^{-6} / \mathrm{K} ; 8 \mathrm{~mol} \% \mathrm{Y}_{2} \mathrm{O}_{3}-\mathrm{ZrO}_{2}$ electrolyte: $10.5 \times 10^{-6} / \mathrm{K}$; stainless steel interconnect: $12-14 \times 10^{-6} / \mathrm{K}$; typical glass seal: $5.5-9.6 \times 10^{-6} / \mathrm{K}$. The new glass composition in this project shows substantially higher CTE than other seal glasses, is close to or even higher than that of the other seal components, and is a promising candidate for further study in SOFC seal applications. The other significance of this result is that the CTEs are different at different temperature ranges. It seems like that the low temperature range $\left(40-500^{\circ} \mathrm{C}\right)$ is the most troublesome with low CTE and is close to the CTE of the seal glass in the literature. The result also pinpoints the area for further improvement. Traditionally, most researches have only been comparing the CTEs across the whole temperature range. This work identifies specific temperature range to improve, $40-500^{\circ} \mathrm{C}$ low temperature range. We also report that the problematic range is in the lower temperature range $\left(40-500^{\circ} \mathrm{C}\right)$ rather than the operation temperature $(800$ $\left.1,000^{\circ} \mathrm{C}\right)$. However, this low temperature range still means significant challenges since this is the transition range during SOFC heating and cooling cycles.

Most encouragingly, the problematic CTE range for the glass coincides with the SMA shape memory effect range. This means the shape memory effect can be utilized to absorb the thermal energy in the glass matrix generated by the thermal stress, provide phase transformation toughening, and self-heal the cracks from the shape recovery of the alloy when engineered properly. 
For the CTE measurement of the SMA, the homogenized SMA ingot is directly used. The thermal expansion is very consistent across the whole temperature range as shown in Figure 16 . From room temperature to $500^{\circ} \mathrm{C}$, the CTE is $17.0 \times 10^{-6} / \mathrm{K}$. From $500^{\circ} \mathrm{C}$ to $800^{\circ} \mathrm{C}$, the $\mathrm{CTE}$ is $17.1 \times 10^{-6} / \mathrm{K}$. From room temperature to $800^{\circ} \mathrm{C}$, the CTE is $16.7 \times 10^{-6} / \mathrm{K}$. This means the SMA has reasonably close CTE to the glass at high temperature and overall. The main CTE difference is at room temperature to $500^{\circ} \mathrm{C}$ range. This confirms again that the main issue for the SOFC seal thermal instability is during the thermal cycling instead of during high temperature operation.

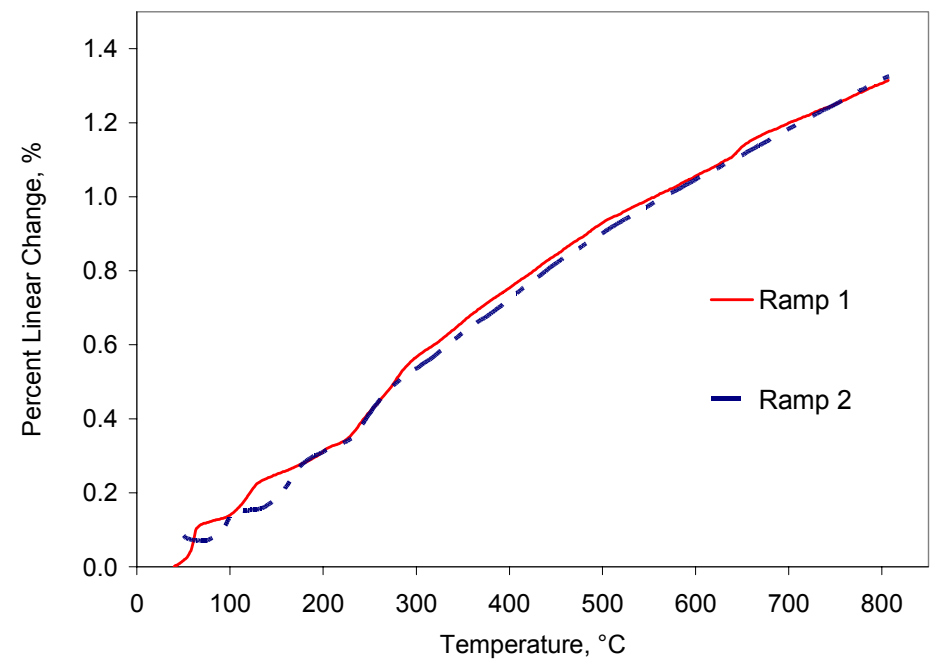

Figure 16. Dilatometry test of SMA CTE under $5^{\circ} \mathrm{C} / \mathrm{min}$ heating/cooling rates.

Figure 17 is the dimensional change curve of the E-Brite stainless steel interconnect during the dilatometry test. The CTE of the E-Brite stainless steel interconnect is $16.8 \times 10^{-6} / \mathrm{K}$. There is some hysteresis during the heating and cooling cycles but the overall results are almost the same. Figure 18 is the dimensional change curve of the scandia stabilized zirconia during the dilatometry test. The CTE of the scandia stabilized zirconia is $9.5 \times 10^{-6} / \mathrm{K}$. For both stainless steel and $\mathrm{ZrO}_{2}$, the CTEs are fairly consistent across the measurement temperature range of room temperature to $800^{\circ} \mathrm{C}$. The CTE of the SLABS glass has been reported as $7.02 \times 10^{-6} /{ }^{\circ} \mathrm{C}$ between $40^{\circ} \mathrm{C}$ and $500^{\circ} \mathrm{C}, 32.0 \times 10^{-6} /{ }^{\circ} \mathrm{C}$ between $500^{\circ} \mathrm{C}$ and $700^{\circ} \mathrm{C}$, and $21.4 \times 10^{-6} /{ }^{\circ} \mathrm{C}$ between 700 $800^{\circ} \mathrm{C}$; the overall CTE is $13.9 \times 10^{-6} /{ }^{\circ} \mathrm{C}$. These measurements confirm the need for CTE match at various temperatures for different SOFC components. 


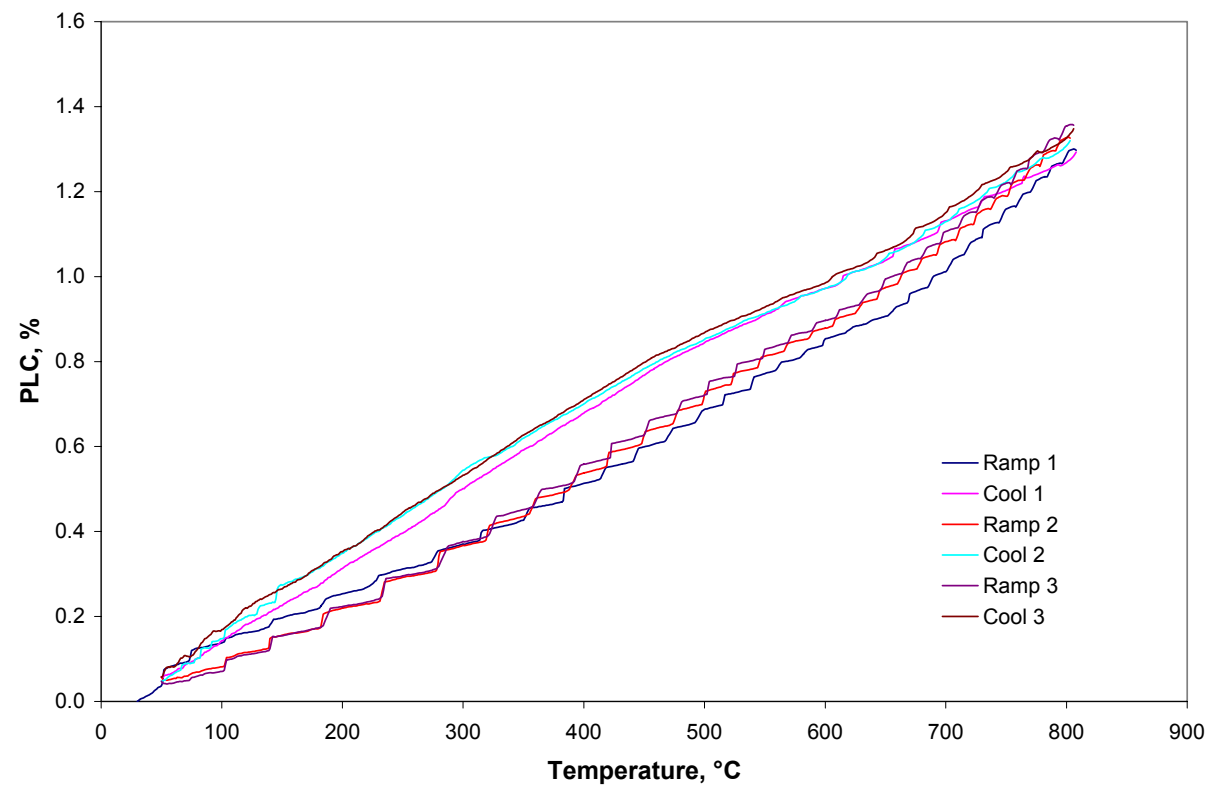

Figure 17. Dilatometry test of the E-Brite stainless steel interconnect CTE under $3^{\circ} \mathrm{C} / \mathrm{min}$ heating/cooling rates.

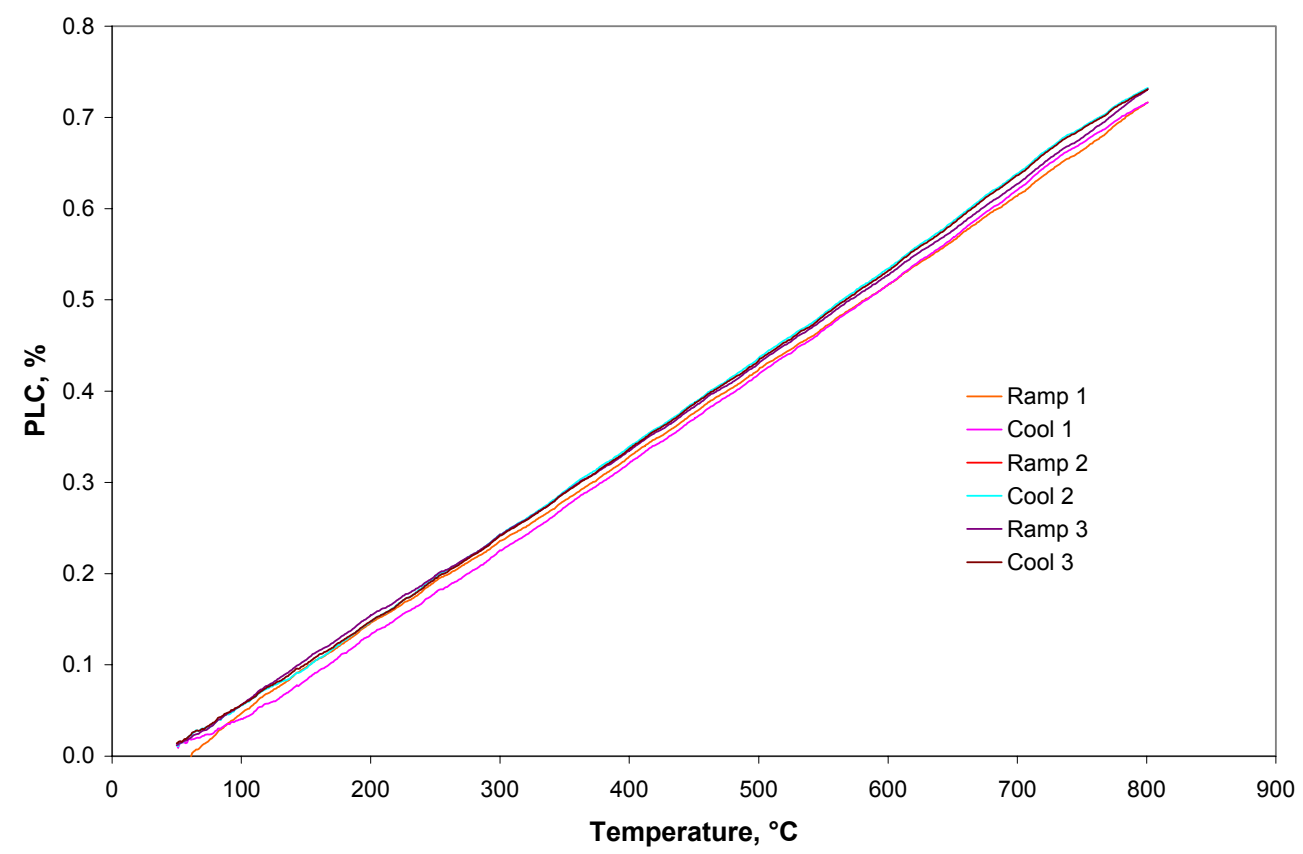

Figure 18. Dilatometry test of $\mathrm{Sc}-\mathrm{ZrO}_{2} \mathrm{CTE}$ under $3^{\circ} \mathrm{C} / \mathrm{min}$ heating/cooling rates.

\section{6) X-Ray Diffraction Pattern of SLABS Glass}

Figure 19 is the XRD patterns of the as-cast and thermally cycled SLABS glass. XRD analysis shows that the SLABS glass is mostly amorphous in the as-cast condition with a small amount of $\mathrm{La}_{2} \mathrm{Sr}_{3}\left(\mathrm{BO}_{3}\right)_{4}$ present. After four thermal cycles, $\mathrm{La}_{2} \mathrm{Sr}_{3}\left(\mathrm{BO}_{3}\right)_{4}$ crystalline phase substantially increases, along with the appearance of $\mathrm{SrLaBO}_{4}$ phase and some un-identified peaks. 

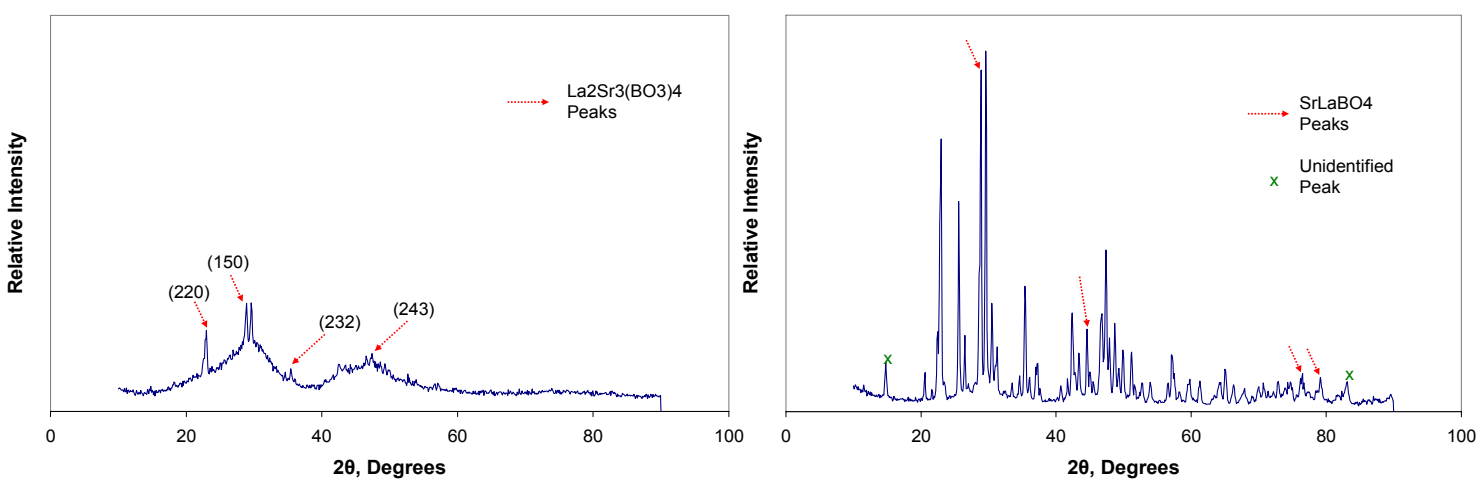

Figure 19. XRD patterns of as-cast and thermally cycled SLABS glass.

\section{7) 3D Printing}

The three dimensional printing machine prints a binder strengthened part from metal powders. The strength and resolution of the part are mostly determined by the variables chosen for printing. Table 1 lists the major variables for the 3D printing, their range, and how they can affect the part.

Table 1: Major Variables used in 3D Printing

\begin{tabular}{|c|c|c|c|}
\hline Name & Range & Details & Effect \\
\hline \multirow[t]{2}{*}{$\begin{array}{l}\text { Spreader Part } \\
\text { Traverse Speed }\end{array}$} & $\begin{array}{l}0.5-5.0 \\
\mathrm{~mm} / \mathrm{sec}\end{array}$ & Part & \multirow[t]{2}{*}{$\begin{array}{l}\text { Affects smoothness of } \\
\text { powder layer on } \\
\text { surface of part box. }\end{array}$} \\
\hline & & Traverse Speed & \\
\hline \multirow{3}{*}{$\begin{array}{l}\text { Feed Powder to } \\
\text { Layer Thickness } \\
\text { Ratio }\end{array}$} & \multirow{3}{*}{$1.0-2.0$} & Ratio $=\frac{\Delta F}{\Delta P}$ & \multirow{3}{*}{$\begin{array}{c}\text { High enough ratio } \\
\text { needed to ensure entire } \\
\text { part build box covered } \\
\text { with a powder layer. } \\
\text { Ratio determined by } \\
\text { particle size and layer } \\
\text { thickness. }\end{array}$} \\
\hline & & 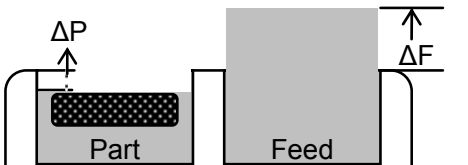 & \\
\hline & & & \\
\hline Drying & $\begin{array}{c}0-90 \mathrm{sec} \\
0-100 \% \\
\text { heater power }\end{array}$ & $\begin{array}{l}\text { Ceramic } \\
\text { Heater } \\
\text { Hom }\end{array}$ & $\begin{array}{l}\text { Binder determines time } \\
\text { and heater power } \\
\text { needed to harden layers } \\
\text { before next layer } \\
\text { spreading. }\end{array}$ \\
\hline $\begin{array}{l}\text { Desired } \\
\text { Saturation }\end{array}$ & $40-200 \%$ & $\begin{array}{l}\text { Volumetric percent of } \\
\text { liquid printed per layer as } \\
\text { compared with volume of } \\
\text { void space between } \\
\text { particles. Powder packing } \\
\text { density needed for this } \\
\text { calculation. }\end{array}$ & $\begin{array}{l}\text { High saturation needed } \\
\text { to create strong bonds } \\
\text { between particles, but } \\
\text { too high a saturation } \\
\text { creates lateral } \\
\text { spreading and } \\
\text { resolution loss. }\end{array}$ \\
\hline
\end{tabular}


First, a 420 stainless steel powder of particle size 45-60 $\mu \mathrm{m}$ and an S-type binder were used to print $100 \mu \mathrm{m}$ thick layers. Since the printing layer was relatively thick, printing variables was maximized to print layers quickly. The spreader traverse speed was set to $3.0-4.0 \mathrm{~mm} / \mathrm{sec}$ depending on the desired resolution. Thick layers did not require a high feed powder to layer thickness ratio so 1.25 was satisfactory. The desired saturation was set as $45 \%$ and this level ensured that the binder fully wetted the particle surfaces. The S-type binder for thick layers did require the drying power control setting to be $90-100 \%$ and the layer drying time to be $45-60$ seconds. After printing, the parts required a pre-cure of $>60$ minutes at full heater power before it was removed from the 3DP machine. A subsequent cure of 2 hours at $180^{\circ} \mathrm{C}$ was necessary to create the highest green strength.

Since the SMA material is fairly expensive (Hf is the main cost followed by $\mathrm{Ti}$ ), we used Ni powder as our practice powder in tailoring the $3 \mathrm{D}$ printing process. $\mathrm{Ni}$ is one of the compositions of the SMA alloy and the knowledge gained from this practice powder should be generally effective for the SMA powders. If very fine wires $(\sim 200-500$ $\mu \mathrm{m})$ of SMA are to be printed, each printed layer must be very thin $(25-50 \mu \mathrm{m})$. The 3DP set-up tailored for the $45 \mu \mathrm{m}$ stainless steel powder cannot spread even layers when the targeted printing layer is less than $100 \mu \mathrm{m}$ thick and the particle size is large; this means the powder used for the $3 \mathrm{D}$ printing has to be switched to smaller particle size. A 1-2 $\mu \mathrm{m}$ Ni powder was obtained (Inco Special Products, Wyckoff, NJ) and printed but the results were unsatisfactory due to the poor flow of the powder. The powder was very prone to agglomeration. A second Ni powder (Inco Special Products, Wyckoff, NJ), 10-15 $\mu \mathrm{m}$ in size as shown in Figure 20a, was obtained with substantially better flowability and was capable of spreading even and smooth layers of $25 \mu \mathrm{m}$ and $50 \mu \mathrm{m}$ thicknesses. This effort proves to be very useful for tailoring the wire thickness to be printed later.

As a further improvement in matching the 3DP parameter-tuning powder with the SMA powder to be actually used in the composite seal, we obtained TiNi powder of $<20$ $\mu \mathrm{m}$ size (Crucible Research, Pittsburg, PA). The TiNi powder composition is $43 \% \mathrm{Ti}$ and $57 \% \mathrm{Ni}$ and is even closer to the SMA composition than that of pure Ni. The powderbinder interaction as well as the sintering behavior of the printed TiNi wire mesh offers further evidence about the feasibility of the 3DP process for the SMA powder. The results show that the printed wire mesh is as strong as what we have achieved for the $\mathrm{Ni}$ powder. It should be noticed in Figure 20 that pure $\mathrm{Ni}$ and TiNi powders have very different surface morphology. Pure Ni powder is very porous and TiNi powder surface is very smooth. During the 3DP process, these two different powders interact and absorb the binder solution very differently. However, we have successfully printed $500 \mu \mathrm{m}$ wire mech for both powders. Also, this work shows that the structure of the particle (porous or dense) is less important than the binder-powder interfacial affinity for the 3DP printing. 


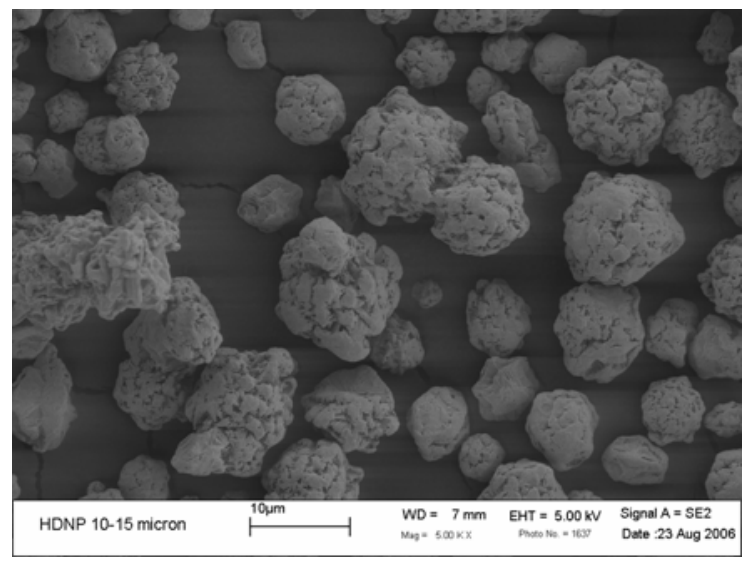

(a)

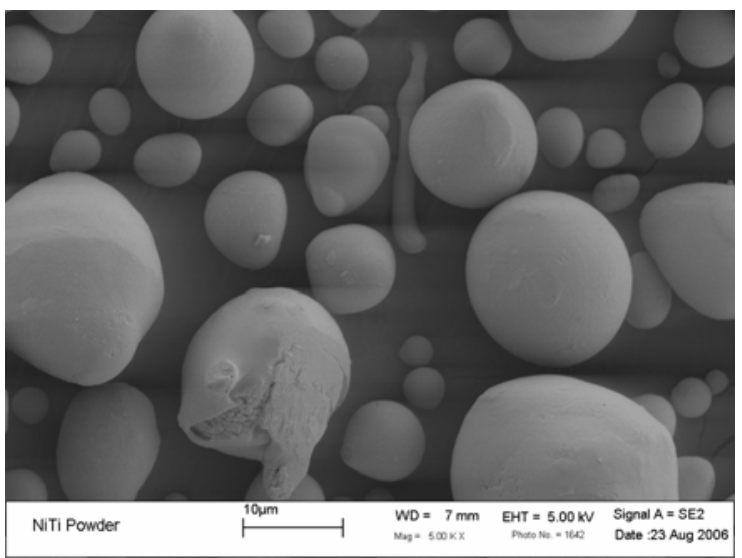

(b)

Figure 20. Pure Ni (a) and TiNi (b) powders used in this program.

Figure 21 is the original $1 \mathrm{~mm}$ wire diameter design printed from the stainless steel powder with Ex-One binder. However, the $\mathrm{Ni}$ powder, the TiNi powder, and subsequently the SMA powder, have very different surface chemistry and particle size than the stainless steel powder that the binder is designed for. The original Ex-One binder solution creates $\mathrm{Ni}$ parts with very low green strength and it is almost impossible to survive the handling process. A binder solution change is necessary to bind the $\mathrm{Ni}$, TiNi, and TiNiHf powder layers together.

Many new binders such as poly(acrylic acid), polymethacrylic acid, polyvinyl alcohol, polyethylene glycol, and emulsion have been investigated with the Ni powder. Various problems are encountered (such as sediment formation, clogging of the 3DP nozzle, poor green strength, etc). The results show that the emulsion creates the strongest wire mesh structures which are capable of being removed from the powder bed and handled before the sintering process. When we transfer the same process to the TiNi powder, the same successful result is obtained. Figure 22 shows the $500 \mu \mathrm{m}$ diameter wire mesh design, the actual wire mesh printed from the Ni powder, and the actual wire mesh printed from the TiNi powder. An additional advantage of the emulsion binder is that there is no need to go through the separate curing process to strengthen the printed part.

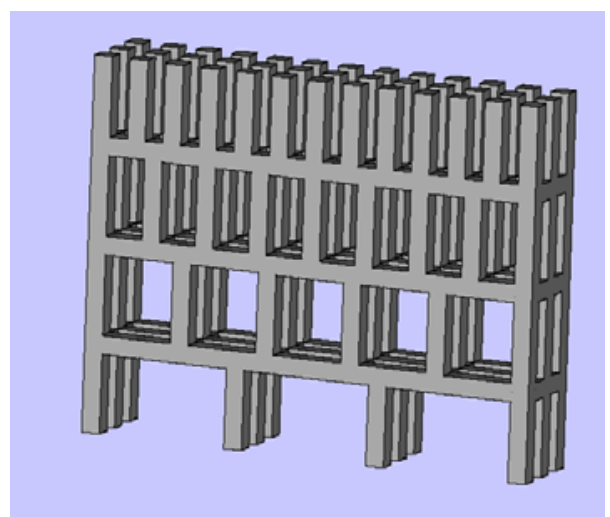

(a)

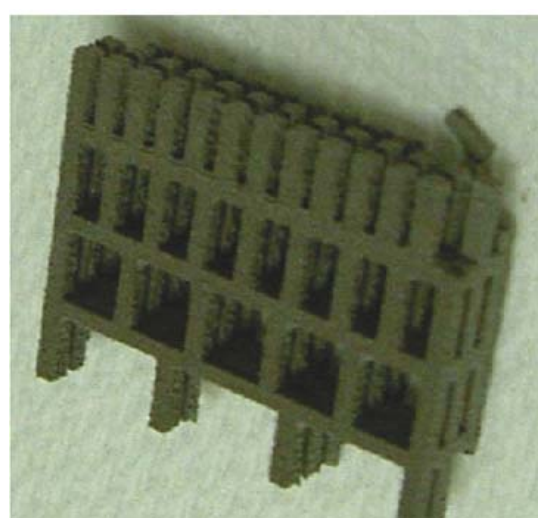

(b)

Figure 21. $1 \mathrm{~mm}$ wire thickness mesh. CAD drawing (a), and the actual part from stainless steel powder (b). 


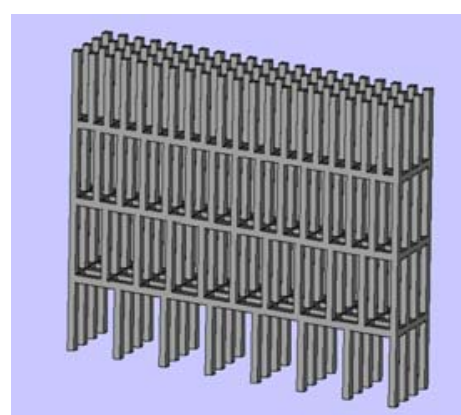

(a)

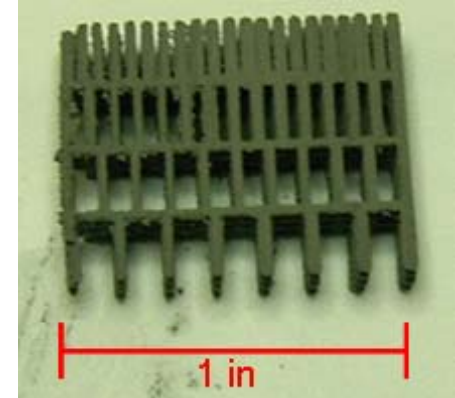

(b)

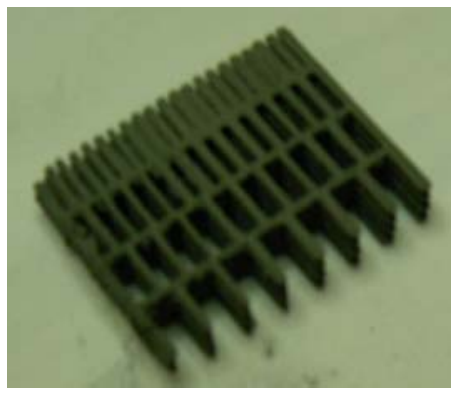

(c)

Figure 22. $500 \mu \mathrm{m}$ thickness wire mesh CAD design (a), pure Ni mesh (b), and TiNi mesh (c). All the objects have the same size.

\section{8) Sintering}

To integrate the TiNi mesh with the SLABS glass, the milled glass powder is poured into the mesh structure. The assembly is placed in a high temperature tube furnace with high purity argon flowing to prevent the oxidation of the wire mesh. The sintering schedule is $5^{\circ} \mathrm{C} / \mathrm{min}$ to $500^{\circ} \mathrm{C}, 2 \mathrm{hr}$ dwell at $500^{\circ} \mathrm{C}, 5^{\circ} \mathrm{C} / \mathrm{min}$ to $950^{\circ} \mathrm{C}, 5 \mathrm{hr}$ dwell at $950^{\circ} \mathrm{C}$, and $5^{\circ} \mathrm{C} / \mathrm{min}$ cooling rate from $950^{\circ} \mathrm{C}$ to room temperature. However, the sintered composite shows cracking.

Two composite seals are sintered to understand the material requirements for sintering seals to SOFC components. NiTi powder from Crucible Research (Pittsburg, PA) was 3-D printed into wire meshes that had a wire diameter of $500 \mu \mathrm{m}$. The binder was the emulsion, the layers were printed at $50 \mu \mathrm{m}$ thicknesses, and after printing, the part was not cured since the emulsion binder does not require curing to reach full strength. The SLABS oxides were spex-milled with $\mathrm{Al}_{2} \mathrm{O}_{3}$ media, melted at $1400^{\circ} \mathrm{C}$, poured into water, and spex-milled with $\mathrm{Al}_{2} \mathrm{O}_{3}$ to create a fine glass frit.

The wire mesh was removed from the excess powder and placed in a rectangular $\mathrm{Al}_{2} \mathrm{O}_{3}$ mold with $\sim 1 \mathrm{~mm}$ extra space on all 4 sides. SLABS frit was sprinkled into the mold and tapped down to fully surround the wires. The first sample was sintered by heating at $5^{\circ} \mathrm{C} / \mathrm{min}$ to $500^{\circ} \mathrm{C}$, held for 2 hours, heated at $5^{\circ} \mathrm{C} / \mathrm{min}$ to $1050^{\circ} \mathrm{C}$, held for 5 hours, and finally cooled to RT at $3^{\circ} \mathrm{C} / \mathrm{min}$. Sintering was performed in a tube furnace under flowing Ar atmosphere. The 2 hour hold at $500^{\circ} \mathrm{C}$ was for burning out the acrylic binder. The SLABS glass had fully sintered, but showed large cracks. Additionally, the SLABS did not fully adhere to the SMA wires. The wires also fully sintered but it seemed that the SLABS had separated from the wires, by coalescing below the wires or pooling above the wires. In addition, most of the SLABS had turned grey by reacting with the SMA.

The second wire mesh was printed with the same conditions, but after printing it was sintered alone before sintering with the glass. It was sintered in the tube furnace under Ar by heating at $5^{\circ} \mathrm{C} / \mathrm{min}$ to $500^{\circ} \mathrm{C}$, held there for 2 hours, heated at $5^{\circ} \mathrm{C} / \mathrm{min}$ to $950^{\circ} \mathrm{C}$, held for 5 hours, and cooled at $5^{\circ} \mathrm{C} / \mathrm{min}$ to RT. The mesh was fully sintered but had a dark grey color indicating surface oxidation. The mesh was placed in an $\mathrm{Al}_{2} \mathrm{O}_{3}$ mold and SLABS frit was sprinkled around the mesh and tamped down. Sintering was first done by heating at $5^{\circ} \mathrm{C} / \mathrm{min}$ to $800^{\circ} \mathrm{C}$, holding for 5 hours, and then cooling at 5 ${ }^{\circ} \mathrm{C} / \mathrm{min}$. When the sample was removed, the SLABS frit was still white, but had not fully 
sintered. Because the frit was not sintered, the part was put back in the tube furnace and sintered with a similar profile but to $900^{\circ} \mathrm{C}$ instead of $800^{\circ} \mathrm{C}$. The SLABS frit had partially sintered into a solid part, but was able to be scratched easily. Additionally, the frit did not fully surround the wires in the mesh similar to the first sample, but the glass did not show cracking.

\section{9) Bi-layer Leak Test}

The sealing is performed by sintering the SLABS glass frit around the SMA wire mesh and to the E-brite and Sc- $\mathrm{ZrO}_{2}$. The SLABS frit is spex milled to $<325$ mesh size and cold pressed with a glycerol binder around the sintered SMA wire mesh. After pressing, a square cavity is cut from the interior of the pressed glass leaving the seal with a thickness of $0.5 \mathrm{~cm}$. Sintering and sealing are performed by heating the assembly in a box furnace at $10^{\circ} \mathrm{C} / \mathrm{min}$ to $800^{\circ} \mathrm{C}$ and holding for 6 hours. When removed from the furnace, the brazed tubing is fitted to the test fixture and an alumina brick is placed under the $\mathrm{Sc}-\mathrm{ZrO}_{2}$ in the tube furnace to support the assembly during testing.

The design for bi-layer leak testing allows for control of temperature and internal pressure of SLABS glass sealed interconnect stainless steel and electrolyte $\mathrm{Sc}^{-} \mathrm{ZrO}_{2}$ samples (Figure 23). 1/4" stainless steel tubing connects a helium tank to the internal chamber of the bi-layer module through a ball valve, a needle valve, a pressure gauge, and a pressure transducer. A National Instruments (Austin, TX) data acquisition meter is used to constantly monitor the pressure from an Omega (Stanford, CT) pressure transducer and temperature from a K-type thermocouple.

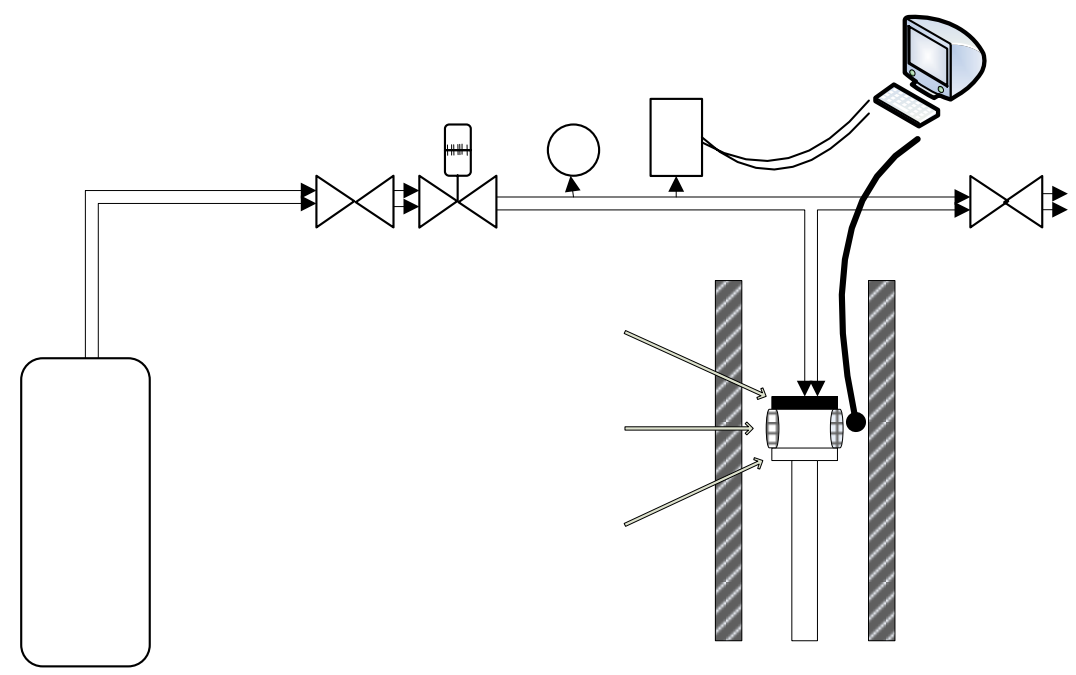

Figure 23. Bi-layer leak testing setup.

At the beginning of the leak tests, the ball valve connected to the He tank is opened to allow slow gas flow to the needle valve. The needle valve is slowly opened until the pressure gauge is at the desired value, and the needle valve and ball valve are closed. The pressure transducer is checked to make sure the digital reading is equivalent to the pressure gauge reading. The initial gas pressure is calculated using the ideal gas law so that at leak testing temperature, the pressure is at the desired value. For calculation, it is assumed that the He temperature inside the tube furnace is at the 
measured temperature, and all $\mathrm{He}$ in the tubing but outside of the furnace is at room temperature. During testing, leak rate is calculated by pressure decrease over time.

The sample assembly for leak testing is composed of 0.02 " thick E-brite stainless steel sheet and 0.011 " thick $\mathrm{Sc}-\mathrm{ZrO}_{2}$ bonded together with the composite seal. The seal outer area is $2.7 \mathrm{~cm} \times 2.7 \mathrm{~cm}$ and the seal is $\sim 0.5 \mathrm{~cm}$ thick. The E-brite sheet is brazed to the test fixture's stainless steel tubing with a $\mathrm{Cu}-\mathrm{Zn}$ bronze so that $\mathrm{He}$ can be pumped into the sealed cavity. It is very important to use the proper heating scheme to properly integrate the seal, interconnect, and electrolyte together. Our work has shown the most desirable approach is to use the densified seal for integration. There is much work in this area to make the perfect seal.

Examining every step of the composite seal manufacturing, the main cost comes from two sources: one is the cost of $\mathrm{Hf}$ and the other is the cost of $3 \mathrm{D}$ printing. Hf is a rare metal that needs to be properly tracked in the procurement process. If a steady supply is established, the cost should decreases. For 3D printing, the equipment we use is the smallest size of its family. When the optimal process is identified, the process can be transferred to large 3DP equipment and multiple 3D meshes can be printed simultaneously. This can substantially reduce the cost. Overall, we expect the cost to be comparable with other sealing processes.

\section{Conclusions}

Based on our research, we can draw the following conclusions:

1) TiNiHf has been successfully synthesized. The shape memory effect has been successfully achieved.

2) Glass melting is easy to achieve but the quenching process needs to be controlled to achieve the desired phase. Our work shows that the unstable phase from fast quenching is undesirable but tends to disappear after the first thermal cycle. Glass milling presents no difficulties.

3) Dilatometry has been used to measure the CTE of the SLABS glass, the commercial cell electrolyte and interconnect. More importantly, it pinpoints regions of different CTEs under the same thermal cycle for the same material. For the studied SLABS glass system, the temperature region with the largest $\mathrm{CTE}$ mismatch is $40-500^{\circ} \mathrm{C}$, exactly in the typical heating and cooling regions for SOFCs.

4) We have demonstrated that the proposed SLABS glass has much higher CTEs than the seal glasses used in the current SOFC research. This glass shows great potential in mitigating the thermal expansion mismatch issues that are hindering the long operation life of SOFC.

5) The TiNiHf SMA shape memory effect very desirably overlaps with the problematic low CTE region of the glass. This is essential for the proposed self-healing mechanism to operate.

6) Extensive work has been carried out for the 3DP parameter optimization. New binder has been identified to effectively bind the new alloy particles. As an additional improvement, binder curing process after the 3DP process can be avoided. 
7) Integration of the wire mesh and the SLABS glass has been attempted. The shrinkage behaviors of the alloy and the glass to achieve simultaneous densification can be further optimized.

8) Neutron diffraction provides $0.001 \AA$ measurement resolution for the TiNiHf alloy lattice parameter change. The thermal stress generated from the glass matrix shifts the SMA austenite to martensite phase transformation temperature to higher temperature during cooling.

\section{Graphic Materials List}

Figure 1. SMA / glass sample for neutron diffraction.

Figure 2. SEM image of the dendrites on the surface of as-melted TiNiHf shape memory alloy.

Figure 3. EDS analysis of the compositions on the surface and in the bulk of the as-melted TiNiHf shape memory alloy.

Figure 4. Optical micrograph of as-melted SMA showing martensite plates within dendrites in (a), martensite-and second-phase precipitates in (b).

Figure 5. Optical micrograph of homogenized SMA showing pure bulk martensite phase after homogenization (a), and surface layer with non-martensite phase and the bulk with martensite phase (b).

Figure 6. SEM micrograph of homogenized SMA showing regions that melted during homogenization (dark regions) and solid phase (gray regions) in the bulk of the sample. The marked locations 1 and 2 are for EDS analysis shown in Figure 7.

Figure 7. EDS analysis of homogenized SMA showing melted pockets (location 1 in Figure 6) has higher Ti content (a) and the solid phase (location 2 in Figure 6) has lower Ti content (b).

Figure 8. Microstructures of the SLABS glass produced by quenching the glass melt directly into water at room temperature (a), and quenching into a graphite mold (b).

Figure 9. Microstructures of the SLABS glass produced by quenching the glass melt directly into a graphite mold. (a): as-quenched, (b) after four thermal cycles.

Figure 10. Differential scanning calorimetry of as-melted shape memory alloy showing no shape memory effect.

Figure 11. Differential scanning calorimetry of homogenized shape memory alloy showing shape memory effect during heating (a) and cooling (b) cycles. (a) shows the austensitic phase transformation start and finish temperatures, and (b) shows the martensitic phase transformation start and finish temperatures.

Figure 12. Neutron diffraction pattern from the SMA/glass sample at $180^{\circ} \mathrm{C}$, $162^{\circ} \mathrm{C}$, and $124^{\circ} \mathrm{C}$. Solid arrow points to austensitic (110) peak and dotted peak points to martensitic (101) and $(020) /(012)$ double peak.

Figure 13. Peak intensity for the (110) austenite peak during cooling.

Figure 14. D-spacing of the (110) austenite peak during cooling. 
Figure 15. Dilatometry test of the SLABS glass CTE under $5^{\circ} \mathrm{C} / \mathrm{min}$ heating/cooling rates.

Figure 16. Dilatometry test of SMA CTE under $5^{\circ} \mathrm{C} / \mathrm{min}$ heating/cooling rates.

Figure 17. Dilatometry test of the E-Brite stainless steel interconnect CTE under $3^{\circ} \mathrm{C} / \mathrm{min}$ heating/cooling rates.

Figure 18. Dilatometry test of $\mathrm{Sc}-\mathrm{ZrO}_{2} \mathrm{CTE}$ under $3{ }^{\circ} \mathrm{C} / \mathrm{min}$ heating/cooling rates.

Figure 19. XRD patterns of as-cast and thermally cycled SLABS glass.

Figure 20. Pure Ni (a) and TiNi (b) powders used in this program.

Figure 21. $1 \mathrm{~mm}$ wire thickness mesh. CAD drawing (a), and the actual part from stainless steel powder (b).

Figure 22. $500 \mu \mathrm{m}$ thickness wire mesh CAD design (a), pure Ni mesh (b), and TiNi mesh (c). All the objects have the same size.

Figure 23. Bi-layer leak testing setup.

\section{References}

1. Alumina as a Ceramic Material, American Ceramic Society, Westerville, $\mathrm{OH}$, p68-70, 1970.

2. Holman, R. K., et al., J. of Colloid and Int. Science, 247, 266-274 (2002).

\section{Publications}

1. K. Lu, C. Story, and W. T. Reynolds, "Three-Dimensional Printing of Gradient Meshed Solid Oxide Fuel Cell Seal Composites" University Coal Research/Historically Black Colleges and Universities and Other Minority Institutions Contractors Review Conference, June 6-7, 2006. Pittsburgh, PA.

2. C. Story, W. Reynolds, and K. Lu, "Shape Memory Alloy / Glass Composite Gas Seal for Solid Oxide Fuel Cells," 2007 TMS Annual Meeting \& Exhibition, February 25, 2007 - March 1, 2007, Orlando, FL.

3. K. Lu, C. Story, and W. T. Reynolds, "Glass/Shape Memory Alloy Composite Study for Solid Oxide Fuel Cell Applications," 31st International Cocoa Beach Conference \& Exposition on Advanced Ceramics and Composites January 21-26, 2007, Daytona Beach, FL.

4. C. Story, K. Yu, K. Lu, and W. T. Reynolds, "Self-Healing Composite Seals for Solid Oxide Fuel Cells," Deans' Form on Energy Security and Survivability, October 16, 2006, Blacksburg, VA. 